\title{
Appendices
}

\section{The \\ Three New Jersey \\ Constitutions}




\section{THE CONSTITUTION OF THE STATE OF NEW JERSEY 1776}

WHEREAS all the constitutional authority ever possessed by the kings of Great Britain over these colonies, || or their other dominions, was, by compact, derived from the people, and held of them, for the common interest of the whole society; allegiance and protection are, in the nature of things, reciprocal ties, each equally depending upon the other, and liable to be dissolved by the others being refused or withdrawn. And whereas George the Third, king of Great Britain, has refused protection to the good people of these colonies; and, by assenting to sundry acts of the British parliament, attempted to subject them to the absolute dominion of that body; and has also made war upon them, in the most cruel and unnatural manner, for no other cause, than asserting their just rights - all civil authority under him is necessarily at an end, and a dissolution of government in each colony has consequently taken place.

And whereas, in the present deplorable situation of these colonies, exposed to the fury of a cruel and relentless enemy, some form of government is absolutely necessary, not only for the preservation of good order, but also the more effectually to unite the people, and enable them to exert their whole force in their own necessary defence: and as the honorable the continental congress, the supreme council of the American colonies, has advised such of the colonies as have not yet gone into measures, to adopt for themselves, respectively, such government as shall best conduce to their own happiness and safety, and the well-being of America in general: - We, the representatives of the colony of New Jersey, having been elected by all the counties, in the freest manner, and in congress assembled, have, after mature deliberations, agreed upon a set of charter rights and the form of a Constitution, in manner following, viz.

I. That the government of this Province shall be vested in a Governor, Legislative Council, and General Assembly.

II. That the Legislative Council, and General Assembly, shall be chosen, for the first time, on the second Tuesday in August next; the members whereof shall be the same in number and qualifications as are herein after mentioned; and shall be and remain vested with all the powers and authority to be held 
by any future Legislative Council and Assembly of this Colony, until the second Tuesday in October, which shall be in the year of our Lord one thousand seven hundred and seventy-seven.

III. That on the second Tuesday in October yearly, and every year forever (with the privilege of adjourning from day to day as occasion may require) the counties shall severally choose one person, to be a member of the Legislative Council of this Colony, who shall be, and have been, for one whole year next before the election, an inhabitant and freeholder in the county in which he is chosen, and worth at least one thousand pounds proclamation money, of real and personal estate, within the same county; that, at the same time, each county shall also choose three members of Assembly; provided that no person shall be entitled to a seat in the said Assembly unless he be, and have been, for one whole year next before the election, an inhabitant of the county he is to represent, and worth five hundred pounds proclamation money, in real and personal estate, in the same county: that on the second Tuesday next after the day of election, the Council and Assembly shall separately meet; and that the consent of both Houses shall be necessary to every law; provided, that seven shall be a quorum of the Council, for doing business, and that no law shall pass, unless there be a majority of all the Representatives of each body personally present, and agreeing thereto. Provided always, that if a majority of the representatives of this Province, in Council and General Assembly convened, shall, at any time or times hereafter, judge it equitable and proper, to add to or diminish the number or proportion of the members of Assembly for any county or counties in this Colony, then, and in such case, the same may, on the principles of more equal representation, be lawfully done; anything in this Charter to the contrary notwithstanding: so that the whole number of Representatives in Assembly shall not, at any time, be less than thirty-nine.

IV. That all inhabitants of this Colony, of full age, who are worth fifty pounds proclamation money, clear estate in the same, and have resided within the county in which they claim a vote for twelve months immediately preceding the election, shall be entitled to vote for Representatives in Council and Assembly; and also for all other public officers, that shall be elected by the people of the county at large. 
V. That the Assembly, when met, shall have power to choose a Speaker, and other their officers; to be judges of the qualifications and elections of their own members; sit upon their own adjournments; prepare bills, to be passed into laws; and to empower their Speaker to convene them, whenever any extraordinary occurrence shall render it necessary.

VI. That the Council shall also have power to prepare bills to pass into laws, and have other like powers as the Assembly, and in all respects be a free and independent branch of the Legislature of this Colony; save only, that they shall not prepare or alter any money bill — which shall be the privilege of the Assembly; that the Council shall, from time to time, be convened by the Governor or Vice-President, but must be convened, at all times, when the Assembly sits; for which purpose the Speaker of the House of Assembly shall always, immediately after an adjournment, give notice to the Governor, or Vice-President, of the time and place to which the House is adjourned.

VII. That the Council and Assembly jointly, at their first meeting after each annual election, shall, by a majority of votes, elect some fit person within the Colony, to be Governor for one year, who shall be constant President of the Council, and have a casting vote in their proceedings; and that the Council themselves shall choose a Vice-President who shall act as such in the absence of the Governor.

VIII. That the Governor, or, in his absence, the Vice- President of the Council, shall have the supreme executive power, be Chancellor of the Colony, and act as captain-general and commander in chief of all the militia, and other military force in this Colony; and that any three or more of the Council shall, at all times, be a privy-council, to consult them; and that the Governor be ordinary or surrogate-general.

IX. That the Governor and Council, (seven whereof shall be a quorum) be the Court of Appeals, in the last resort, in all clauses of law, as heretofore; and that they possess the power of granting pardons to criminals, after condemnation, in all cases of treason, felony, or other offences.

$\mathrm{X}$. That captains, and all other inferior officers of the militia, shall be chosen by the companies, in the respective counties; but field and general officers, 
by the Council and Assembly.

XI. That the Council and Assembly shall have power to make the Great Seal of this Colony, which shall be kept by the Governor, or in his absence, by the Vice-President of the Council, to be used by them as occasion may require: and it shall be called, The Great Seal of the Colony of New-Jersey.

XII. That the Judges of the Supreme Court shall continue in office for seven years: the Judges of the Inferior Court of Common Pleas in the several counties, Justices of the Peace, Clerks of the Supreme Court, Clerks of the Inferior Court of Common Pleas and Quarter Sessions, the AttorneyGeneral, and Provincial Secretary, shall continue in office for five years: and the Provincial Treasurer shall continue in office for one year; and that they shall be severally appointed by the Council and Assembly, in manner aforesaid, and commissioned by the Governor, or, in his absence, the Vice-President of the Council. Provided always, that the said officers, severally, shall be capable of being re-appointed, a the end of the terms severally before limited; and that any of the said officers shall be liable to be dismissed, when adjudged guilty of misbehaviour, by the Council, on an impeachment of the Assembly.

XIII. That the inhabitants of each county, qualified to vote as aforesaid, shall at the time and place of electing their Representatives, annually elect one Sheriff, and one or more Coroners; and that they may re-elect the same person to such offices until he shall have served three years, but no longer; after which, three years must elapse before the same person is capable of being elected again. When the election is certified to the Governor, or VicePresident, under the hands of six freeholders of the county for which they were elected, they shall be immediately commissioned to serve in their respective offices.

XIV. That the townships, at their annual town meetings for electing other officers, shall choose constables for the districts respectively; and also three or more judicious freeholders of good character, to hear and finally determine all appeals relative to unjust assessments, in cases of public taxation; which commissioners of appeal shall, for that purpose, sit at some suitable time or times, to be by them appointed, and made known to the people by advertisements. 
XV. That the laws of the Colony shall begin in the following style, viz. "Be it enacted by the Council and Generally Assembly of this Colony, and it is hereby enacted by authority of the same:" that all commissions, granted by the Governor or Vice- President, shall run thus — "The Colony of NewJersey to A. B. \&c. greeting:" and that all writs shall likewise run in the name of the Colony: and that all indictments shall conclude in the following manner, viz. "Against the peace of this Colony, the government and dignity of the same."

XVI. That all criminals shall be admitted to the same privileges of witnesses and counsel, as their prosecutors are or shall be entitled to.

XVII. That the estates of such persons as shall destroy their own lives, shall not, for that offence, be forfeited; but shall descend in the same manner, as they would have done, had such persons died in the natural way; nor shall any article, which may occasion accidentally the death of any one, be henceforth deemed a deod and, or in any wise forfeited, on account of such misfortune.

XVIII. That no person shall ever, within this Colony, be deprived of the inestimable privilege of worshipping Almighty God in a manner agreeable to the dictates of his own conscience; nor, under any pretence whatever, be compelled to attend any place of worship, contrary to his own faith and judgment; nor shall any person, within this Colony, ever be obliged to pay tithes, taxes or any other rates, for the purpose of building or repairing any other church or churches, place or places of worship, or for the maintenance of any minister or ministry, contrary to what he believes to be right, or has deliberately or voluntarily engaged himself to perform.

XIX. That there shall be no establishment of any one religious sect in this Province, in preference to another; and that no Protestant inhabitant of this Colony shall be denied the enjoyment of any civil right, merely on account of his religious principles; but that all persons, professing a belief in the faith of any Protestant sect, who shall demean themselves peaceably under the government, as hereby established, shall be capable of being elected into any office of profit or trust, or being a member of either branch of the Legislature, and shall fully and freely enjoy every privilege and immunity, enjoyed by others their fellow subjects. 


\section{THE CONSTITUTION OF THE STATE OF NEW JERSEY 1844}

We, the people of the State of New Jersey, grateful to Almighty God for the civil and religious liberty which He hath so permitted us to enjoy, and looking to Him for a blessing upon our endeavors to secure and transmit the same unimpaired to succeeding generations, do ordain and establish this constitution.

ARTICLE I.

RIGHTS AND PRIVILEGES.

One. All men are by nature free and independent, and have certain natural and unalienable rights, among which are those of enjoying and defending life and liberty, acquiring, possessing, and protecting property, and of pursuing and obtaining safety and happiness.

Two. All political power is inherent in the people. Government is instituted for the protection, security, and benefit of the people, and they have the right at all times to alter or reform the same, whenever the public good may require it.

Three. No person shall be deprived of the inestimable privilege of worshipping Almighty God in a manner agreeable to the dictates of his own conscience; nor under any pretence whatever be compelled to attend any place of worship contrary to his faith and judgment; nor shall any person be obliged to pay tithes, taxes, or other rates for building or repairing any church or churches, place or places of worship, or for the maintenance of any minister or ministry, contrary to what he believes to be right, or has deliberately and voluntarily engaged to perform.

Four. There shall be no establishment of one religious sect in preference to another; no religious test shall be required as a qualification for any office or public trust; and no person shall be denied the enjoyment of any civil right merely on account of his religious principles.

Five. Every person may freely speak, write, and publish his sentiments on all 
subjects, being responsible for the abuse of that right. No law shall be passed to restrain or abridge the liberty of speech or of the press. In all prosecutions or indictments for libel, the truth may be given in evidence to the jury; and if it shall appear to the jury that the matter charged as libelous is true, and was published with good motives and for justifiable ends, the party shall be acquitted; and the jury shall have the right to determine the law and the fact.

Six. The right of the people to be secure in their persons, houses, papers, and effects, against unreasonable searches and seizures, shall not be violated; and no warrant shall issue but upon probable cause, supported by oath or affirmation, and particularly describing the place to be searched and the papers and things to be seized.

Seven. The right of trial by jury shall remain inviolate; but the legislature may authorize the trial of civil suits, when the matter in dispute does not exceed fifty dollars, by a jury of six men.

Eight. In all criminal prosecutions the accused shall have a right to a speedy and public trial by an impartial jury; to be informed of the nature and cause of the accusation; to be confronted with the witnesses against him; to have compulsory process for obtaining witnesses in his favor, and to have the assistance of counsel in his defence.

Nine. No person shall be held to answer for a criminal offence, unless on the presentment or indictment of a grand jury, except in cases of impeachment, or in cases cognizable by justices of the peace, or arising in the army or navy; or in the militia, when in actual service in time of war or public danger.

Ten. No person shall, after acquittal, be tried for the same offence. All persons shall, before conviction, be bailable by sufficient sureties, except for capital offences, when the proof is evident or presumption great.

Eleven. The privilege of the writ of habeas corpus shall not be suspended, unless in case of rebellion or invasion the public safety may require it. 
Twelve. The military shall be in strict subordination to the civil power.

Thirteen. No soldier shall, in time of peace, be quartered in any house without the consent of the owner, nor in time of war, except in a manner prescribed by law.

Fourteen. Treason against the State shall consist only in levying war against it, or in adhering to its enemies, giving them aid and comfort. No person shall be convicted of treason, unless on the testimony of two witnesses to the same overt act, or on confession in open court.

Fifteen. Excessive bail shall not be required, excessive fines shall not be imposed, and cruel and unusual punishments shall not be inflicted.

Sixteen. Private property shall not be taken for public use, without just compensation; but land may be taken for public highways, as heretofore, until the legislature shall direct compensation to be made.

Seventeen. No person shall be imprisoned for debt in any action or on any judgment founded upon contract, unless in case of fraud; nor shall any person be imprisoned for a militia fine in time of peace.

Eighteen. The people have the right freely to assemble together to consult for the common good, to make known their opinions to their representatives, and to petition for redress of grievances.

Nineteen. This enumeration of rights and privileges shall not be construed to impair or deny others retained by the people.

ARTICLE II.

RIGHT OF SUFFRAGE.

One. Every white male citizen of the United States, of the age of twentyone years, who shall have been a resident of this State one year, and of the county in which he claims his vote five months, next before the election, 
shall be entitled to vote for all officers that now are, or hereafter may be, elective by the people: Provided, That no person in the military, naval, or marine service of the United States shall be considered a resident in this State, by being stationed in any garrison, barrack, or military or naval place or station within this State; and no pauper, idiot, insane person, or person convicted of a crime which now excludes him from being a witness, unless pardoned or restored by law to the right of suffrage, shall enjoy the right of an elector.

Two. The legislature may pass laws to deprive persons of the right of suffrage who shall be convicted of bribery at elections.

ARTICLE III.

DISTRIBUTION OF THE POWERS OF GOVERNMENT.

The powers of the government shall be divided into three distinct departments- the legislative, executive, and judicial; and no person or persons belonging to or constituting one of these departments shall exercise any of the powers properly belonging to either of the others, except as herein expressly provided.

ARTICLE IV.

LEGISLATIVE

SECTION I. One. The legislative power shall be vested in a senate and general assembly.

Two. No person shall be a member of the senate who shall not have attained the age of thirty years, and have been a citizen and inhabitant of the State for four years, and of the county for which he shall be chosen one year, next before his election; and no person shall be a member of the general assembly who shall not have attained the age of twenty-one years, and have been a citizen and inhabitant of the State for two years, and of the county for which he shall be chosen one year next before his election: Provided, That no person shall be eligible as a member of either house of the legislature, 
who shall not be entitled to the right of suffrage.

Three. Members of the senate and general assembly shall be elected yearly and every year, on the second Tuesday of October; and the two houses shall meet separately on the second Tuesday in January next after the said day of election; at which time of meeting the legislative year shall commence; but the time of holding such election may be altered by the legislature.

SEC. 2. One. The senate shall be composed of one senator from each county in the State, elected by the legal voters of the counties, respectively, for three years:

Two. As soon as the senate shall meet after the first election to be held in pursuance of this constitution, they shall be divided as equally as may be into three classes. The seats of the senators of the first class shall be vacated at the expiration of the first year; of the second class at the expiration of the second year, and of the third class at the expiration of the third year, so that one class may be elected every year; and if vacancies happen by resignation or otherwise, the persons elected to supply such vacancies shall be elected for the unexpired terms only.

SEC. 3. One. The general assembly shall be composed of members annually elected by the legal voters of the counties, respectively, who shall be apportioned among the said counties as nearly as may be according to the number of their inhabitants. The present apportionment shall continue until the next census of the United States shall have been taken, and an apportionment of members of the general assembly shall be the legislature at its first session after the next and every subsequent enumeration or census, and when made shall remain unaltered until another enumeration shall have been taken: Provided, That each county shall at all times be entitled to one member; and the whole number of members shall never exceed sixty.

SEC. 4. One. Each house shall direct writs of election for supplying vacancies occasioned by death, resignation, or otherwise; but if vacancies occur during the recess of the legislature, the writs may be issued by the governor, under such regulations as may be prescribed by law. 
Two. Each house shall be the judge of the elections, returns, and qualifications of its own members, and a majority of each shall constitute a quorum to do business, but a smaller number may adjourn from day to day, and may be authorized to compel the attendance of absent members, in such manner and under such penalties as each house shall provide.

Three. Each house shall choose its own officers, determine the rules of its proceedings, punish its members for disorderly behavior, and, with the concurrence of two-thirds, may expel a member.

Four. Each house shall keep a journal of its proceedings, and from time to time publish the same; and the yeas and nays of the members of either house on any question shall, at the desire of one-fifth of those present, be entered on the journal.

Five. Neither house, during the session of the legislature, shall, without the consent of the other, adjourn for more than three days, nor to any other place than that in which the two houses shall be sitting.

Six. All bills and joint resolutions shall be read three times in each house before the final passage thereof, and no bill or joint resolution shall pass unless there be a majority of all the members of each body personally present and agreeing thereto, and the yeas and nays of members voting on such final passage shall be entered on the journal.

Seven. Members of the senate and general assembly shall receive a compensation for their services, to be ascertained by law, and paid out of the treasury of the State, which compensation shall not exceed the sum of three dollars per day for the period of forty days from the commencement of the session, and shall not exceed the sum of one dollar and fifty cents per day for the remainder of the session. When convened in extra session by the governor, they shall receive such sum as shall be fixed for the first forty days of the ordinary session. They shall also receive the sum of one dollar for every ten miles they shall travel in going to and returning from their place of meeting, on the most usual route. The president of the senate and the speaker of the house of assembly shall, in virtue of their offices, receive an additional compensation, equal to one-third of their per diem allowance as 
members.

Eight. Members of the senate or of the general assembly shall, in all cases except treason, felony, and breach of peace, be privileged from arrest during their attendance at the sitting of their respective houses and in going to and returning from the same; and for any speech or debate, in either house, they shall not be questioned in any other place.

SEC. 5. One. No member of the senate and general assembly shall, during the time for which he was elected, be nominated or appointed by the governor, or by the legislature in joint meeting, to any civil office under the authority of this State which shall have been created or the emoluments whereof shall have been increased during such time.

Two. If any member of the senate or general assembly shall be elected to represent this State in the Senate or House of Representatives of the United States, and shall accept thereof, or shall accept of any office or appointment under the Government of the United States, his seat in the legislature of this State shall thereby be vacated.

Three. No justice of the supreme court, nor judge of any other court, sheriff, justice of the peace, nor any person or persons possessed of any office of profit under the government of this State shall be entitled to a seat either in the senate or in the general assembly; but on being elected and taking his seat his office shall be considered vacant, and no person holding any office of profit under the Government of the United States shall be entitled to a seat in either house.

Sec. 6. One. All bills for raising revenue shall originate in the house of assembly, but the Senate may propose or concur with amendments, as on other bills.

Two. No money shall be drawn from the treasury but for appropriations made by law.

Three. The credit of the State shall not be directly or indirectly loaned in any case. 
Four. The legislature shall not, in any manner, create any debt or debts, liability or liabilities of the State, which shall singly or in the aggregate, with any previous debts or liabilities, at any time exceed one hundred thousand dollars, except for purposes of war, or to repel invasion, or to suppress insurrection, unless the same shall be authorized by a law for some single object or work, to be distinctly specified therein, which law shall provide the ways and means, exclusive of loans, to pay the interest of each debt or liability as it falls due, and also to pay and discharge the principal of such debt or liability within thirty-five years from the time of the contracting thereof, and shall be irrepealable until such debt or liability, and the interest thereon, are fully paid and discharged, and no such law shall take effect until it shall, at a general election, have been submitted to the people, and have received the sanction of a majority of all the votes cast for and against it at such election, and all money to be raised by the authority of such law shall be applied only to the specific object stated therein, and to the payment of the debt thereby created. This section shall not be construed to refer to any money that has been or may be deposited with this State by the Government of the United States.

SEC 7. One. No divorce shall be granted by the legislature.

Two. No lottery shall be authorized by this State, and no ticket in any lottery not authorized by a law of this State shall be bought or sold within the State.

Three. The legislature shall not pass any bill of attainder, ex post facto law, or law impairing the obligation of contracts, or depriving a party of any remedy for enforcing a contract which existed when the contract was made.

Four. To avoid improper influences which may result from intermixing in one and the same act such as have no proper relation to each other, every law shall embrace but one object, and that shall be expressed in the title.

Five. The laws of this State shall begin in the following style: "Be it enacted by the senate and great assembly of the State of New Jersey." 
Six. The fund for the support of free schools, and all money, stock, and other property which may hereafter be appropriated for that purpose, or received into the treasury under the provision of any law heretofore paid to augment the said fund, shall be securely invested and remain a perpetual fund, and the income thereof, except so much as it may be judged expedient to apply to an increase of the capital, shall be annually appropriated to the support of public schools, for the equal benefit of all the people of the State, and it shall not be competent for the legislature to borrow, appropriate, or use the said fund, or any part thereof, for any other purpose under any pretence whatever.

Seven. No private or special law shall be passed authorizing the sale of any lands belonging in whole or in part to a minor or minors, or other persons who may at the time be under any legal disability to act for themselves.

Eight. The assent of three-fifths of the members elected to each house shall be requisite to the passage of every law for granting, continuing, altering, amending, or renewing charters for banks or money corporations, and all such charters shall be limited to a term not exceeding twenty years.

Nine. Individuals or private corporations shall not be authorized to take private property for public use without just compensation first made to the owners.

Ten. The legislature may vest in the circuit courts or courts of common pleas within the several counties of this State chancery powers, so far as relates to the foreclosure of mortgages and sale of mortgaged premises.

Sec. 8. Members of the legislature shall, before they enter on the duties of their respective offices, take and subscribe the following oath or affirmation:

"I do solemnly swear or affirm, as the case may be that I will support the Constitution of the United States and the constitution of the State of New Jersey, and that I will faithfully discharge the duties of senator or member of the general assembly, as the case may be according to the best of my ability." 
And members-elect of the senate or general assembly are hereby empowered to administer to each other the said oath or affirmation.

\section{ARTICLEV.}

EXECUTIVE.

One. The executive power shall be vested in a governor.

Two. The governor shall be elected by the legal voters of this State. The person having the highest number of votes shall be the governor; but if two or more shall be equal and highest in votes, one of them shall be chosen governor by the vote of a majority of the members of both houses in joint meeting. Contested elections for the office of governor shall be determined in such manner as the legislature shall direct by law. When a governor is to be elected by the people, such election shall be held at the time when and at the places where the people shall respectively vote for members of the legislature.

Three. The governor shall hold his office for three years, to commence on the third Tuesday of January next ensuing the election for governor by the people, and to end on the Monday preceding the third Tuesday of January, three years thereafter, and he shall be incapable of holding that office for three years next after his term of service shall have expired, and no appointment or nomination to office shall be made by the governor during the last week of his said term.

Four. The governor shall be not less than thirty years of age, and shall have been for twenty years, at least, a citizen of the United States, and a resident of this State seven years next before his election, unless he shall have been absent during that time on the public business of the United States or of this State.

Five. The governor shall, at stated times, receive for his services a compensation which shall be neither increased nor diminished during the period for which he shall have been elected.

Six. He shall be the commander-in-chief of all the military and naval forces 
of the State; he shall have power to convene the legislature whenever in his opinion public necessity requires it; he shall communicate by message to the legislature at the opening of each session, and at such other times as he may deem necessary, the condition of the State, and recommend such measures as he may deem expedient; he shall take care that the laws be faithfully executed, and grant, under the great seal of the State, commissions to all such officers as shall be required to be commissioned.

Seven. Every bill which shall have passed both houses shall be presented to the governor; if he approve he shall sign it, but if not he shall return it, with his objections, to the house in which it shall have originated, who shall enter the objections at large on their journal and proceed to reconsider it; if, after such reconsideration. a majority of the whole number of that house shall agree to pass the bill, it shall be sent, together with the objections, to the other house, by which it shall likewise be reconsidered and if approved of by a majority of the whole number of that house, it shall become a law; but in neither house shall the vote be taken on the same day on which the bill shall be returned to it, and in all such cases the votes of both houses shall be determined by yeas and nays, and the names of the persons voting for and against the bill shall be entered on the journal of each house respectively. If any bill shall not be returned by the governor within five days (Sundays excepted) after it shall have been presented to him, the same shall be a law in like manner as if he had signed it, unless the legislature, by their adjournment, prevent its return, in which case it shall not be a law.

Eight. No member of Congress or person holding an office under the United States or this State shall exercise the office of governor, and in case the governor, or person administering the government, shall accept of any office under the United States or this State, his office of governor shall thereupon be vacant.

Nine. The governor, or person administering the government, shall have power to suspend the collection of fines and forfeitures, and to grant reprieves to extend until the expiration of a time not exceeding ninety days, after conviction, but this power shall not extend to cases of impeachment.

Ten. The governor, or person administering the government, the chancellor, 
and the six judges of the court of errors and appeals, or a major part of them, of whom the governor, or person administering the government, shall be one, may remit fines and forfeitures and grant pardons, after conviction, in all cases except impeachment.

Eleven. The governor and all other officers under this State shall be liable to impeachment for misdemeanor in office, during their continuance in office, and for two years thereafter.

Twelve. In case of the death, resignation, or removal from office of the governor, the powers, duties, and emoluments of the office shall devolve upon the president of the senate, and in case of his death, resignation, or removal, then upon the speaker of the house of assembly, for the time being, until another governor shall be elected and qualified, but in such case another governor shall be chosen at the next election for members of the State legislature, unless such death, resignation, or removal shall occur within thirty days immediately preceding such next election, in which case a governor shall be chosen at the second succeeding election for members of the legislature. When a vacancy happens during the recess of the legislature, in any office which is to be filled by the governor and senate, or by the legislature, in joint meeting, the governor shall fill such vacancy, and the commission shall expire at the end of the next session of the legislature, unless a successor shall be sooner appointed. When a vacancy happens in the office of clerk or surrogate of any county, the governor shall fill such vacancy, and the commission shall expire when a successor is elected and qualified.

Thirteen. In case of the impeachment of the governor, his absence from the State, or inability to discharge the duties of his office, the powers, duties, and emoluments of the office shall devolve upon the president of the senate; and in case of his death, resignation, or removal, then upon the speaker of the house of assembly, for the time being, until the governor absent or impeached shall return or be acquitted, or until the disqualification or inability shall cease, or until a new governor be elected and qualified.

Fourteen. In case of a vacancy in the office of governor, from any other cause than those herein enumerated, or in case of the death of the governorelect, before he is qualified into office, the powers, duties, and emoluments 
of the office shall devolve upon the president of the senate or speaker of the house of assembly, as above provided for, until a new governor be elected and qualified.

ARTICLEVI.

JUDICIARY.

Section I4. The judicial power shall be vested in a court of errors and appeals in the last resort in all causes, as heretofore; a court for the trial of impeachments; a court of chancery; a prerogative court; a supreme court; circuit courts, and such inferior courts as now exist, and as may be hereafter ordained and established by law; which inferior courts the legislature may alter or abolish, as the public good shall require.

SEC. 2. One. The court of errors and appeals shall consist of the chancellor, the justices of the supreme court, and six judges, or a major part of them; which judges are to be appointed for six years.

Two. Immediately after the court shall first assemble, the six judges shall arrange themselves in such manner that the seat of one of them shall be vacated every year, in order that thereafter one judge may be annually appointed.

Three. Such of the six judges as shall attend the court shall receive respectively a per diem compensation, to be provided by law.

Four. The secretary of state shall be the clerk of this court.

Five. When an appeal from an order or decree shall be heard, the chancellor shall inform the court, in writing, of the reason for his order or decree; but he shall not sit as a member, or have a voice in the hearing or final sentence.

Six. When a writ of error shall be brought, no justice who has given a judicial opinion in the cause, in failure of or against any error complained of, shall sit as a member, or have a voice on the hearing, or for its affirmance or reversal; but the reasons for such opinion shall be assigned to the court in writing. 
Sec. 3. One. The house of assembly shall have the sole power of impeaching, by a vote of a majority of all the members; and all impeachments shall be tried by the senate; the members when sitting for that purpose to be on oath or affirmation, truly and impartially to try and determine the charge in question according to evidence; and no person shall be convicted without the concurrence of two-thirds of all the members of the senate.

Two. Any judicial officer impeached shall be suspended from exercising his office until his acquittal.

Three. Judgment, in cases of impeachment, shall not extend farther than to removal from office and to disqualification to hold and enjoy any office of honor, profit, or trust under this State; but the partly convicted shall nevertheless be liable to indictment, trial, and punishment, according to law.

Four. The secretary of state shall be the clerk of this court.

Sec. 4. One. The court of chancery shall consist of a chancellor.

Two. The chancellor shall be the ordinary, or surrogate general, and judge of the prerogative court.

Three. All persons aggrieved by any order, sentence, or decree of the orphans' court, may appeal from the same, or from any part thereof, to the prerogative court; but such order, sentence, or decree shall not be removed into the supreme court, or circuit court, if the subject matter thereof be within the jurisdiction of the orphans' court.

Four. The secretary of state shall be the register of the prerogative court, and shall perform the duties required of him by law in that respect.

Sec. 5. One. The supreme court shall consist of a chief justice and four associate justices. The number of associate justices may be increased or decreased by law, but shall never be less than two.

Two. The circuit courts shall be held in every county of this State, by one or 
more of the justices of the supreme court, or a judge appointed for that purpose, and shall, in all cases within the county, except in those of a criminal nature, have common law jurisdiction concurrent with the supreme court, and any final judgment of a circuit court may be docketed in the supreme court, and shall operate as a judgment obtained in the supreme court from the time of such docketing.

Three. Final judgments in any circuit court may be brought by writ of error into the supreme court, or directly into the court of errors and appeals.

SEC. 6. One. There shall be no more than five judges of the inferior court of common pleas in each of the counties in this State after the terms of the judges of said court now in office shall terminate. One judge for each county shall be appointed every year, and no more, except to fill vacancies, which shall be for the unexpired term only.

Two. The commissions for the appointments of judges of said court shall bear date and take effect on the first day of April next, and all subsequent commissions for judges of said court shall bear date and take effect on the first day of April in every successive year, except commissions to fill vacancies, which shall bear date and take effect when issued.

SEC. 7. One. There may be elected under this constitution two and not more than five justices of the peace in each of the townships of the several counties of this State, and in each of the wards in cities that may vote in wards. When a township or ward contains two thousand inhabitants or less, it may have two justices; when it contains more than two thousand inhabitants, and not more than four thousand, it may have four justices; and when it contains more than four thousand inhabitants, it may have five justices: Provided, That whenever any township not voting in wards contains more than seven thousand inhabitants, such township may have an additional justice for each additional three thousand inhabitants above four thousand.

Two. The population of the townships in the several counties of the State and of the several wards shall be ascertained by the last preceding census of the United States, until the legislature shall provide by law some other mode of ascertaining it. 
ARTICLEVII.

APPOINTING POWER AND TENURE OF OFFICE. Militia Officers.

SECTION I. One. The legislature shall provide by law for enrolling, organizing, and arming the militia.

Two. Captains, subalterns, and non-commissioned officers shall be elected by the members of their respective companies.

Three. Field officers of regiments, independent battalions, and squadrons shall be elected by the commissioned officers of their respective regiments, battalions, or squadrons.

Four. Brigadier generals shall be elected by the field officers of their respective brigades.

Five. Major generals shall be nominated by the governor, and appointed by him, with the advice and consent of the senate.

Six. The legislature shall provide by law the time and manner of electing militia officers and of certifying their elections to the governor, who shall grant their commissions and determine their rank, when not determined by law, and no commissioned officer shall be removed from office but by the sentence of a court martial pursuant to law.

Seven. In case the electors of subalterns, captains, or field officers shall refuse or neglect to make such elections, the governor shall have power to appoint such officers, and to fill all vacancies caused by such refusal or neglect.

Eight. Brigade inspectors shall be chosen by the field officers of their respective brigades.

Nine. The governor shall appoint the adjutant general, quartermaster general, and all other militia officers whose appointment is nor otherwise provided 
for in this constitution.

Ten. Major generals, brigadier generals, and commanding officers of regiments, independent battalions, and squadrons, shall appoint the staff officers of their divisions, brigades, regiments, independent battalions, and squadrons, respectively.

\section{Civil Officers.}

SEC. 2. One. Justices of the supreme court, chancellor, and judges of the court of errors and appeals shall be nominated by the governor, and appointed by him, with the advice and consent of the senate.

The justices of the supreme court and chancellor shall hold their offices for the term of seven years; shall, at stated times, receive for their services a compensation which shall not be diminished during the term of their appointments; and they shall hold no other office under the government of this State or of the United States.

Two. Judges of the courts of common pleas shall be appointed by the senate and general assembly, in joint meeting.

They shall hold their offices for five years; but when appointed to fill vacancies, they shall hold for the unexpired term only.

Three. The State treasurer and the keeper and inspectors of the State prison shall be appointed by the senate and general assembly, in joint meeting.

They shall hold the offices for one year, and until their successors shall be qualified into office.

Four. The attorney-general prosecutors of pleas, clerk of the supreme court, clerk of the court of chancery, and secretary of state shall be nominated by the governor, and appointed by him, with the advice and consent of the senate. They shall hold their offices five years.

Five. The law-reporter shall be appointed by the justices of the supreme 
court, or a majority of them; and the chancery reporter shall be appointed by the chancellor. They shall hold their offices for five years.

Six. Clerks and surrogates of counties shall be elected by the people of their respective counties at the annual elections for members of the general assembly.

They shall hold their offices for five years.

Seven. Sheriffs and coroners shall be elected annually by the people of their respective counties, at the annual elections for members of the general assembly.

They may be reelected until they have served three years, but no longer; after which three years must elapse before they can be again capable of serving.

Eight. Justices of the peace shall be elected by ballot, at the annual meetings of the townships in the several counties of the State, and of the wards in the cities that may vote in wards, in such manner, under such regulations, as may be hereafter provided by law.

They shall be commissioned for the county, and their commissions shall bear date and take effect on the first day of May next after their election.

They shall hold their offices for five years, but when elected to fill vacancies, they shall hold for the unexpired term only: Provided, That the commission of any justice of the Peace shall become vacant upon his ceasing to reside in the township in which he was elected.

The first election for justices of the peace shall take place at the next annual town meetings of the townships in the several counties of the State, and of the wards in cities that may vote in wards.

Nine. All other officers, whose appointments are not otherwise provided for by law, shall be nominated by the governor, and appointed by him, with the advice and consent of the senate; and shall hold their offices for the time prescribed by law. 
Ten. All civil officers elected or appointed pursuant to the provisions of this constitution, shall be commissioned by the governor.

Eleven. The term of the office of all officers elected or appointed pursuant to the provisions of this constitution, except when herein otherwise directed, shall commence on the day of the date of their respective commissions; but no commission or any office shall bear date prior to the expiration of the term of the incumbent of said office.

ARTICLE VIII.

GENERAL PROVISIONS.

One. The secretary of state shall be ex officio an auditor of the accounts of the treasurer, and, as such, it shall be his duty to assist the legislature in the annual examination and settlement of said accounts, until otherwise provided by law.

Two. The seal of the State shall be kept by the governor or person administering the government, and used by him officially, and shall be called "The Great Seal of the State of New Jersey."

Three. All grants and commissions shall be in the name and by the authority of the State of New Jersey, sealed with the great seal, signed by the governor or person administering the government and countersigned by the secretary of state, and shall run thus: "The State of New Jersey to - -, greeting." All writs shall be in the name of the State; and all indictments shall conclude in the following viz: "Against the peace of this State, the government and dignity of the same."

Four. This constitution shall take effect and go into operation on the second day of September, in the year of our Lord one thousand eight hundred and forty-four. 
ARTICLE IX

AMENDMENTS

Any specific amendment or amendments to the constitution may be proposed in the senate or general assembly, and if the same shall be agreed to by a majority of the members elected to each of the two houses, such proposed amendment or amendments shall be entered on their journals, with the yeas and nays taken and referred to the legislature then next to be chosen, and shall be published, for three months previous to making such choice, in at least one newspaper of each county, if any be published therein; and if in the legislature next chosen, as aforesaid, such proposed amendment or amendments, or any of them, shall be agreed to by a majority of all the members elected to each house, then it shall be the duty of the legislature to submit such proposed amendment or amendments, or such of them as have been agreed to as aforesaid by the two legislatures, to the people, in such manner and at such time, at least four months after the adjournment of the legislature, as the legislature shall prescribe; and if the people, at a special election to be held for that purpose only, shall approve and ratify such amendment or amendments, or any of them, by a majority of the electors qualified to vote for members of the legislature voting thereon, such amendment or amendments, so approved and ratified, shall become part of the constitution: Provided, That if more than one amendment be submitted, they shall be submitted in such manner and form that the people may vote for or against each amendment separately and distinctly; but no amendment or amendments shall be submitted to the people by the legislature oftener than once in five years.

\section{ARTICLE X}

SCHEDULE

That no inconvenience may arise from the change in the constitution of this State, and in order to carry the same into complete operation, it is hereby declared and ordained that- -

SECTION I. The common law and statute laws now in force not repugnant to this constitution, shall remain in force until they expire by their own limitation, or be altered or repealed by the legislature; and all writs, actions, 
causes of action, prosecution, contracts, claims, and rights of individuals and of bodies-corporate, and of the State and all charters of incorporation shall continue, and all indictments which shall have been found, or which may hereafter be found, for any crime or offence committed before the adoption of this constitution, may be proceeded upon as if no several courts of law and equity, except as herein otherwise provided, shall continue with the like powers and jurisdiction as if this constitution had not been adopted.

SEC. 2. All officers now filling any office or appointment shall continue in the exercise of the duties thereof, according to their respective commissions or appointments. unless by this constitution it is otherwise directed.

SEC. 3. The present governor, chancellor, and ordinary or surrogate general, and treasurer, shall continue in office until successors elected or appointed under this constitution shall be sworn or affirmed into office.

SEC 4. In case of the death, resignation, or disability of the present governor, the person who may be vice-president of council at the time of the adoption of this constitution shall continue in office, and administer the government until a governor shall have been elected and sworn or affirmed into office under this constitution.

SEC. 5. The present governor, or in case of his death or inability to act, the vice-president of council, together with the present members of the legislative council and secretary of state, shall constitute a board of State canvassers, in the manner now provided by law, for the purpose of ascertaining and declaring the result of the next ensuing election for governor, members of the house of representatives, and electors of President and Vice-President.

SEC. 6. The returns of the votes for governor, at the said next ensuing election, be submitted to the secretary of state, the votes counted, and the election in the manner now provided by law in the case of the election of electors of President and Vice-President.

SEC. 7. The election of clerks and surrogates, in those counties where the term of office of the present incumbent shall expire previous to the general election of eighteen hundred and forty-five, shall be held at the general 
election next ensuing the adoption of this constitution; the result of which election shall be ascertained in the manner now provided by law for the election of sheriffs.

SEC. 8. The elections for the year eighteen hundred and forty-four shall take place a now provided by law.

SEC. 9. It shall be the duty of the governor to fill all vacancies in office happening between the adoption of this constitution and the first session of the senate, and not otherwise provided for; and the commissions shall expire at the end of the first session of the senate, or when successors shall be elected or appointed and qualified.

SEC. IO. The restriction of the pay of members of the legislature, after forty days from the commencement of the session, shall not be applied to the first legislature convened under this constitution.

SEC. I I. Clerks of counties shall be clerks of the inferior courts of common pleas and quarter sessions of the several counties, and perform the duties, and be subject to the regulations now required of them by law, until otherwise ordained by the legislature.

SEC. I2. The legislature shall pass all laws necessary to carry into effect the provisions of this constitution.

Done in convention, at the State House in Trenton, on the twenty-ninth day of June, in the year of our Lord one thousand eight hundred and forty-four, and of the Independence of the United States of America the sixty-eighth.

ALEXANDER WURTZ, President.

WILLIAM PATERSON, Secretary.

Tn. J. SAUNDERS, Assistant Secretary. 


\section{CONSTITUTION OF THE STATE OF NEW JERSEY 1947}

A Constitution agreed upon by the delegates of the people of New Jersey, in Convention, begun at Rutgers University, the State University of New Jersey, in New Brunswick, on the twelfth day of June, and continued to the tenth day of September, in the year of our Lord one thousand nine hundred and forty-seven.

We, the people of the State of New Jersey, grateful to Almighty God for the civil and religious liberty which He hath so long permitted us to enjoy, and looking to Him for a blessing upon our endeavors to secure and transmit the same unimpaired to succeeding generations, do ordain and establish this Constitution.

\section{ARTICLE I RIGHTS AND PRIVILEGES}

I. All persons are by nature free and independent, and have certain natural and unalienable rights, among which are those of enjoying and defending life and liberty, of acquiring, possessing, and protecting property, and of pursuing and obtaining safety and happiness.

2. a. All political power is inherent in the people. Government is instituted for the protection, security, and benefit of the people, and they have the right at all times to alter or reform the same, whenever the public good may require it.

b. The people reserve unto themselves the power to recall, after at least one year of service, any elected official in this State or representing this State in the United States Congress. The Legislature shall enact laws to provide for such recall elections. Any such laws shall include a provision that a recall election shall be held upon petition of at least $25 \%$ of the registered voters in the electoral district of the official sought to be recalled. If legislation to implement this constitutional amendment is not enacted within one year of the adoption of the amendment, the Secretary of State shall, by regulation, implement the constitutional amendment, except that regulations adopted by the Secretary of State shall be superseded by any subsequent legislation consistent with this constitutional amendment governing recall elections. The sufficiency of any statement of reasons or grounds procedurally required shall be a political rather than a judicial question.

3. No person shall be deprived of the inestimable privilege of worshipping Almighty God in a manner agreeable to the dictates of his own conscience; 
nor under any pretense whatever be compelled to attend any place of worship contrary to his faith and judgment; nor shall any person be obliged to pay tithes, taxes, or other rates for building or repairing any church or churches, place or places of worship, or for the maintenance of any minister or ministry, contrary to what he believes to be right or has deliberately and voluntarily engaged to perform.

4. There shall be no establishment of one religious sect in preference to another; no religious or racial test shall be required as a qualification for any office or public trust.

5. No person shall be denied the enjoyment of any civil or military right, nor be discriminated against in the exercise of any civil or military right, nor be segregated in the militia or in the public schools, because of religious principles, race, color, ancestry or national origin.

6. Every person may freely speak, write and publish his sentiments on all subjects, being responsible for the abuse of that right. No law shall be passed to restrain or abridge the liberty of speech or of the press. In all prosecutions or indictments for libel, the truth may be given in evidence to the jury; and if it shall appear to the jury that the matter charged as libelous is true, and was published with good motives and for justifiable ends, the party shall be acquitted; and the jury shall have the right to determine the law and the fact.

7. The right of the people to be secure in their persons, houses, papers, and effects, against unreasonable searches and seizures, shall not be violated; and no warrant shall issue except upon probable cause, supported by oath or affirmation, and particularly describing the place to be searched and the papers and things to be seized.

8. No person shall be held to answer for a criminal offense, unless on the presentment or indictment of a grand jury, except in cases of impeachment, or in cases now prosecuted without indictment, or arising in the army or navy or in the militia, when in actual service in time of war or public danger.

9. The right of trial by jury shall remain inviolate; but the Legislature may authorize the trial of civil causes by a jury of six persons. The Legislature may provide that in any civil cause a verdict may be rendered by not less than five-sixths of the jury. The Legislature may authorize the trial of the issue of mental incompetency without a jury.

I0. In all criminal prosecutions the accused shall have the right to a speedy and public trial by an impartial jury; to be informed of the nature and cause 
of the accusation; to be confronted with the witnesses against him; to have compulsory process for obtaining witnesses in his favor; and to have the assistance of counsel in his defense.

I I. No person shall, after acquittal, be tried for the same offense. All persons shall, before conviction, be bailable by sufficient sureties, except for capital offenses when the proof is evident or presumption great.

I2. Excessive bail shall not be required, excessive fines shall not be imposed, and cruel and unusual punishments shall not be inflicted. It shall not be cruel and unusual punishment to impose the death penalty on a person convicted of purposely or knowingly causing death or purposely or knowingly causing serious bodily injury resulting in death who committed the homicidal act by his own conduct or who as an accomplice procured the commission of the offense by payment or promise of payment of anything of pecuniary value.

I3. No person shall be imprisoned for debt in any action, or on any judgment found upon contract, unless in cases of fraud; nor shall any person be imprisoned for a militia fine in time of peace.

I4. The privilege of the writ of habeas corpus shall not be suspended, unless in case of rebellion or invasion the public safety may require it.

I5. The military shall be in strict subordination to the civil power.

I6. No soldier shall, in time of peace, be quartered in any house, without the consent of the owner; nor in time of war, except in a manner prescribed by law.

I7. Treason against the State shall consist only in levying war against it, or in adhering to its enemies, giving them aid and comfort. No person shall be convicted of treason, unless on the testimony of two witnesses to the same overt act, or on confession in open court.

I8. The people have the right freely to assemble together, to consult for the common good, to make known their opinions to their representatives, and to petition for redress of grievances.

19. Persons in private employment shall have the right to organize and bargain collectively. Persons in public employment shall have the right to organize, present to and make known to the State, or any of its political subdivisions or agencies, their grievances and proposals through representatives of their own choosing. 
20. Private property shall not be taken for public use without just compensation. Individuals or private corporations shall not be authorized to take private property for public use without just compensation first made to the owners.

2I. This enumeration of rights and privileges shall not be construed to impair or deny others retained by the people.

22. A victim of a crime shall be treated with fairness, compassion and respect by the criminal justice system. A victim of a crime shall not be denied the right to be present at public judicial proceedings except when, prior to completing testimony as a witness, the victim is properly sequestered in accordance with law or the Rules Governing the Courts of the State of New Jersey. A victim of a crime shall be entitled to those rights and remedies as may be provided by the Legislature. For the purposes of this paragraph, "victim of a crime" means: a) a person who has suffered physical or psychological injury or has incurred loss of or damage to personal or real property as a result of a crime or an incident involving another person operating a motor vehicle while under the influence of drugs or alcohol, and b) the spouse, parent, legal guardian, grandparent, child or sibling of the decedent in the case of a criminal homicide. Article I, paragraph 2 amended effective January I, I994; paragraph 9 amended effective December 4, I973; paragraph I2 amended effective December 3, I992; paragraph 22 added effective December 5, I99I.

\section{ARTICLE II ELECTIONS AND SUFFRAGE SECTION I}

I. General elections shall be held annually on the first Tuesday after the first Monday in November; but the time of holding such elections may be altered by law. The Governor and members of the Legislature shall be chosen at general elections. Local elective officers shall be chosen at general elections or at such other times as shall be provided by law.

2. All questions submitted to the people of the entire State shall be voted upon at the general election next occurring at least 70 days following the final action of the Governor or the Legislature, as appropriate, necessary to submit the questions. The text of any such question shall be published at least once in one or more newspapers of each county, if any newspapers be published therein, at least 60 days before the election at which it is to be submitted to the people, and the results of the vote upon a question shall be void unless the text thereof shall have been so published. Article II, paragraph 
2 amended effective December 8, 1988.

3. (a) Every citizen of the United States, of the age of I8 years, who shall have been a resident of this State and of the county in which he claims his vote 30 days, next before the election, shall be entitled to vote for all officers that now are or hereafter may be elective by the people, and upon all questions which may be submitted to a vote of the people; and

(b) (Deleted by amendment, effective December 5, 1974.) (c) Any person registered as a voter in any election district of this State who has removed or shall remove to another state or to another county within this State and is not able there to qualify to vote by reason of an insufficient period of residence in such state or county, shall, as a citizen of the United States, have the right to vote for electors for President and Vice President of the United States, only, by Presidential Elector Absentee Ballot, in the county from which he has removed, in such manner as the Legislature shall provide. Article II, paragraph 3 amended effective December 5,1974.

4. In time of war no elector in the military service of the State or in the armed forces of the United States shall be deprived of his vote by reason of absence from his election district. The Legislature may provide for absentee voting by members of the armed forces of the United States in time of peace. The Legislature may provide the manner in which and the time and place at which such absent electors may vote, and for the return and canvass of their votes in the election district in which they respectively reside.

5. No person in the military, naval or marine service of the United States shall be considered a resident of this State by being stationed in any garrison, barrack, or military or naval place or station within this State.

6. No idiot or insane person shall enjoy the right of suffrage.

7. The Legislature may pass laws to deprive persons of the right of suffrage who shall be convicted of such crimes as it may designate. Any person so deprived, when pardoned or otherwise restored by law to the right of suffrage, shall again enjoy that right.

\section{SECTION II}

I. (a) After each federal census taken in a year ending in zero, the Congressional districts shall be established by the New Jersey Redistricting Commission. The commission shall consist of $\mathrm{I} 3$ members, none of whom shall be a member or employee of the Congress of the United States. The 
members of the commission shall be appointed with due consideration to geographic, ethnic and racial diversity and in the manner provided herein. (b) There shall first be appointed 12 members as follows: (I) two members to be appointed by the President of the Senate; (2) two members to be appointed by the Speaker of the General Assembly; (3) two members to be appointed by the minority leader of the Senate; (4) two members to be appointed by the minority leader of the General Assembly; and (5) four members, two to be appointed by the chairman of the State committee of the political party whose candidate for the office of Governor received the largest number of votes at the most recent gubernatorial election and two to be appointed by the chairman of the State committee of the political party whose candidate for the office of Governor received the next largest number of votes in that election. Appointments to the commission under this subparagraph shall be made on or before June I5 of each year ending in one and shall be certified by the respective appointing officials to the Secretary of State on or before July I of that year. Each partisan delegation so appointed shall appoint one of its members as its chairman who shall have authority to make such certifications and to perform such other tasks as the members of that delegation shall reasonably require. (c) There shall then be appointed one member, to serve as an independent member, who shall have been for the preceding five years a resident of this State, but who shall not during that period have held public or party office in this State. The independent member shall be appointed upon the vote of at least seven of the previously appointed members of the commission on or before July I5 of each year ending in one, and those members shall certify that appointment to the Secretary of State on or before July 20 of that year. If the previously appointed members are unable to appoint an independent member within the time allowed therefor, they shall so certify to the Supreme Court not later than that July 20 and shall include in that certification the names of the two persons who, in the members' final vote upon the appointment of the independent member, received the greatest number of votes. Not later than August IO following receipt of that certification, the Supreme Court shall by majority vote of its full authorized membership select, of the two persons so named, the one more qualified by education and occupational experience, by prior public service in government or otherwise, and by demonstrated ability to represent the best interest of the people of this State, to be the independent member. The Court shall certify that selection to the Secretary 
of State not later than the following August I5. (d) Vacancies in the membership of the commission occurring prior to the certification by the commission of Congressional districts or during any period in which the districts established by the commission may be or are under challenge in court shall be filled in the same manner as the original appointments were made within five days of their occurrence. In the case of a vacancy in the membership of the independent member, if the other members of the commission are unable to fill that vacancy within that five-day period, they shall transmit certification of such inability within three days of the expiration of the period to the Supreme Court, which shall select the person to fill the vacancy within five days of receipt of that certification.

2. The independent member shall serve as the chairman of the commission. The commission shall meet to organize as soon as may be practicable after certification of the appointment of the independent member, but not later than the Wednesday after the first Monday in September of each year ending in one. At the organizational meeting the members of the commission shall determine such organizational matters as they deem appropriate. Thereafter, a meeting of the commission may be called by the chairman or upon the request of seven members, and seven members of the commission shall constitute a quorum at any meeting thereof for the purpose of taking any action.

3. On or before the third Tuesday of each year ending in two, or within three months after receipt in each decade by the appropriate State officer of the official statement by the Clerk of the United States House of Representatives, issued pursuant to federal law, regarding the number of members of the House of Representatives apportioned to this State for that decade, whichever is later, the commission shall certify the establishment of the Congressional districts to the Secretary of State. The commission shall certify the establishment of districts pursuant to a majority vote of the full authorized membership of the commission convened in open public meeting, of which meeting there shall be at least 24 hours' public notice. Any vote by the commission upon a proposal to certify the establishment of a Congressional district plan shall be taken by roll call and shall be recorded, and the vote of any member in favor of any Congressional district plan shall nullify any vote which that member shall previously have cast during the life of the commission in favor of a different Congressional district plan. If the commission is unable to certify the establishment of districts by the time 
required due to the inability of a plan to achieve seven votes, the two district plans receiving the greatest number of votes, but not fewer than five votes, shall be submitted to the Supreme Court, which shall select and certify whichever of the two plans so submitted conforms most closely to the requirements of the Constitution and laws of the United States.

4. The New Jersey Redistricting Commission shall hold at least three public hearings in different parts of the State. The commission shall, subject to the constraints of time and convenience, review written plans for the establishment of Congressional districts submitted by members of the public.

5. Meetings of the New Jersey Redistricting Commission shall be held at convenient times and locations and, with the exception of the public hearings required by paragraph 4 of this section and the meeting at which the establishment of districts is certified as prescribed by paragraph 3 of this section, may be closed to the public.

6. The Legislature shall appropriate the funds necessary for the efficient operation of the New Jersey Redistricting Commission.

7. Notwithstanding any provision to the contrary of this Constitution and except as otherwise required by the Constitution or laws of the United States, no court of this State other than the Supreme Court shall have jurisdiction over any judicial proceeding challenging the appointment of members to the New Jersey Redistricting Commission, or any action, including the establishment of Congressional districts, by the commission or other public officer or body under the provisions of this section.

8. The establishment of Congressional districts shall be used thereafter for the election of members of the House of Representatives and shall remain unaltered through the next year ending in zero in which a federal census for this State is taken.

9. If a plan certified by the commission is declared unlawful, the commission shall reorganize and adopt another Congressional district plan in the same manner as herein required and within the period of time prescribed by the court or within such shorter period as may be necessary to ensure that the new plan is effective for the next succeeding primary and general election for all members of the United States House of Representatives. Article II, section II added effective December 7, 1995. 


\section{ARTICLE III DISTRIBUTION OF THE POWERS OF GOVERNMENT}

I. The powers of the government shall be divided among three distinct branches, the legislative, executive, and judicial. No person or persons belonging to or constituting one branch shall exercise any of the powers properly belonging to either of the others, except as expressly provided in this Constitution.

\section{ARTICLE IV LEGISLATIVE SECTION I}

I. The legislative power shall be vested in a Senate and General Assembly.

2. No person shall be a member of the Senate who shall not have attained the age of thirty years, and have been a citizen and resident of the State for four years, and of the district for which he shall be elected one year, next before his election. No person shall be a member of the General Assembly who shall not have attained the age of twenty-one years and have been a citizen and resident of the State for two years, and of the district for which he shall be elected one year, next before his election. No person shall be eligible for membership in the Legislature unless he be entitled to the right of suffrage. Article IV, Section I, paragraph 2 amended effective December 8, 1966.

3. Each Legislature shall be constituted for a term of 2 years beginning at noon on the second Tuesday in January in each even numbered year, at which time the Senate and General Assembly shall meet and organize separately and the first annual session of the Legislature shall commence. Said first annual session shall terminate at noon on the second Tuesday in January next following, at which time the second annual session shall commence and it shall terminate at noon on the second Tuesday in January then next following but either session may be sooner terminated by adjournment sine die. All business before either House or any of the committees thereof at the end of the first annual session may be resumed in the second annual session. The legislative year shall commence at noon on the second Tuesday in January of each year. Article IV, Section I, paragraph 3 amended effective December 3, 1968. (Applicable to the 1970 Legislature and thereafter.)

4. Special sessions of the Legislature shall be called by the Governor upon petition of a majority of all the members of each house, and may be called by the Governor whenever in his opinion the public interest shall require. 


\section{SECTION II}

I. The Senate shall be composed of forty senators apportioned among Senate districts as nearly as may be according to the number of their inhabitants as reported in the last preceding decennial census of the United States and according to the method of equal proportions. Each Senate district shall be composed, wherever practicable, of one single county, and, if not so practicable, of two or more contiguous whole counties.

2. Each senator shall be elected by the legally qualified voters of the Senate district, except that if the Senate district is composed of two or more counties and two senators are apportioned to the district, one senator shall be elected by the legally qualified voters of each Assembly district. Each senator shall be elected for a term beginning at noon of the second Tuesday in January next following his election and ending at noon of the second Tuesday in January four years thereafter, except that each senator, to be elected for a term beginning in January of the second year following the year in which a decennial census of the United States is taken, shall be elected for a term of two years.

3. The General Assembly shall be composed of eighty members. Each Senate district to which only one senator is apportioned shall constitute an Assembly district. Each of the remaining Senate districts shall be divided into Assembly districts equal in number to the number of senators apportioned to the Senate district. The Assembly districts shall be composed of contiguous territory, as nearly compact and equal in the number of their inhabitants as possible, and in no event shall each such district contain less than eighty per cent nor more than one hundred twenty per cent of one-fortieth of the total number of inhabitants of the State as reported in the last preceeding decennial census of the United States. Unless necessary to meet the foregoing requirements, no county or municipality shall be divided among Assembly districts unless it shall contain more than one-fortieth of the total number of inhabitants of the State, and no county or municipality shall be divided among a number of Assembly districts larger than one plus the whole number obtained by dividing the number of inhabitants in the county or municipality by one-fortieth of the total number of inhabitants of the State.

4. Two members of the General Assembly shall be elected by the legally qualified voters of each Assembly district for terms beginning at noon of the second Tuesday in January next following their election and ending at 
noon of the second Tuesday in January two years thereafter. Article IV, Section II, paragraphs I, 2, 3, 4 amended effective December 8, 1966.

\section{SECTION III}

I. After the next and every subsequent decennial census of the United States, the Senate districts and Assembly districts shall be established, and the senators and members of the General Assembly shall be apportioned among them, by an Apportionment Commission consisting of ten members, five to be appointed by the chairman of the State committee of each of the two political parties whose candidates for Governor receive the largest number of votes at the most recent gubernatorial election. Each State chairman, in making such appointments, shall give due consideration to the representation of the various geographical areas of the State. Appointments to the Commission shall be made on or before November 15 of the year in which such census is taken and shall be certified by the Secretary of State on or before December I of that year. The Commission, by a majority of the whole number of its members, shall certify the establishment of Senate and Assembly districts and the apportionment of senators and members of the General Assembly to the Secretary of State within one month of the receipt by the Governor of the official decennial census of the United States for New Jersey, or on or before February I of the year following the year in which the census is taken, whichever date is later.

2. If the Apportionment Commission fails so to certify such establishment and apportionment to the Secretary of State on or before the date fixed or if prior thereto it determines that it will be unable so to do, it shall so certify to the Chief Justice of the Supreme Court of New Jersey and he shall appoint an eleventh member of the Commission. The Commission so constituted, by a majority of the whole number of its members, shall, within one month after the appointment of such eleventh member, certify to the Secretary of State the establishment of Senate and Assembly districts and the apportionment of senators and members of the General Assembly.

3. Such establishment and apportionment shall be used thereafter for the election of members of the Legislature and shall remain unaltered until the following decennial census of the United States for New Jersey shall have been received by the Governor. Article IV, Section III, paragraphs I, 2, 3 amended effective December 8, 1966. 


\section{SECTION IV}

I. Any vacancy in the Legislature occasioned otherwise than by expiration of term shall be filled by election for the unexpired term only at the next general election occurring not less than 5I days after the occurrence of the vacancy, except that no vacancy shall be filled at the general election which immediately precedes the expiration of the term in which the vacancy occurs. For the interim period pending the election and qualification of a successor to fill the vacancy, or for the remainder of the term in the case of a vacancy occurring which cannot be filled pursuant to the terms of this paragraph at a general election, the vacancy shall be filled within 35 days by the members of the county committee of the political party of which the incumbent was the nominee from the municipalities or districts or units thereof which comprise the legislative district. Article IV, Section IV, paragraph I amended effective December 8, 1988.

2. Each house shall be the judge of elections, returns and qualifications of its own members, and a majority of all its members shall constitute a quorum to do business; but a smaller number may adjourn from day to day, and may be authorized to compel the attendance of absent members, in such manner, and under such penalties, as each house may provide.

3. Each house shall choose its own officers, determine the rules of its proceedings, and punish its members for disorderly behavior. It may expel a member with the concurrence of two-thirds of all its members.

4. Each house shall keep a journal of its proceedings, and from time to time publish the same. The yeas and nays of the members of either house on any question shall, on demand of one-fifth of those present, be entered on the journal.

5. Neither house, during the session of the Legislature, shall, without the consent of the other, adjourn for more than three days, or to any other place than that in which the two houses shall be sitting.

6. All bills and joint resolutions shall be read three times in each house before final passage. No bill or joint resolution shall be read a third time in either house until after the intervention of one full calendar day following the day of the second reading; but if either house shall resolve by vote of three-fourths of all its members, signified by yeas and nays entered on the journal, that a bill or joint resolution is an emergency measure, it may proceed forthwith from second to third reading. No bill or joint resolution shall 
pass, unless there shall be a majority of all the members of each body personally present and agreeing thereto, and the yeas and nays of the members voting on such final passage shall be entered on the journal.

7. Members of the Senate and General Assembly shall receive annually, during the term for which they shall have been elected and while they shall hold their office, such compensation as shall, from time to time, be fixed by law and no other allowance or emolument, directly or indirectly, for any purpose whatever. The President of the Senate and the Speaker of the General Assembly, each by virtue of his office, shall receive an additional allowance, equal to one-third of his compensation as a member.

8. The compensation of members of the Senate and General Assembly shall be fixed at the first session of the Legislature held after this Constitution takes effect, and may be increased or decreased by law from time to time thereafter, but no increase or decrease shall be effective until the legislative year following the next general election for members of the General Assembly.

9. Members of the Senate and General Assembly shall, in all cases except treason and high misdemeanor, be privileged from arrest during their attendance at the sitting of their respective houses, and in going to and returning from the same; and for any statement, speech or debate in either house or at any meeting of a legislative committee, they shall not be questioned in any other place.

\section{SECTION V}

I. No member of the Senate or General Assembly, during the term for which he shall have been elected, shall be nominated, elected or appointed to any State civil office or position, of profit, which shall have been created by law, or the emoluments whereof shall have been increased by law, during such term. The provisions of this paragraph shall not prohibit the election of any person as Governor or as a member of the Senate or General Assembly.

2. The Legislature may appoint any commission, committee or other body whose main purpose is to aid or assist it in performing its functions. Members of the Legislature may be appointed to serve on any such body.

3. If any member of the Legislature shall become a member of Congress or shall accept any Federal or State office or position, of profit, his seat shall thereupon become vacant.

4. No member of Congress, no person holding any Federal or State office 
or position, of profit, and no judge of any court shall be entitled to a seat in the Legislature.

5. Neither the Legislature nor either house thereof shall elect or appoint any executive, administrative or judicial officer except the State Auditor.

\section{SECTION VI}

I. All bills for raising revenue shall originate in the General Assembly; but the Senate may propose or concur with amendments, as on other bills.

2. The Legislature may enact general laws under which municipalities, other than counties, may adopt zoning ordinances limiting and restricting to specified districts and regulating therein, buildings and structures, according to their construction, and the nature and extent of their use, and the nature and extent of the uses of land, and the exercise of such authority shall be deemed to be within the police power of the State. Such laws shall be subject to repeal or alteration by the Legislature.

3. Any agency or political subdivision of the State or any agency of a political subdivision thereof, which may be empowered to take or otherwise acquire private property for any public highway, parkway, airport, place, improvement, or use, may be authorized by law to take or otherwise acquire a fee simple absolute or any lesser interest, and may be authorized by law to take or otherwise acquire a fee simple absolute in, easements upon, or the benefit of restrictions upon, abutting property to preserve and protect the public highway, parkway, airport, place, improvement, or use; but such taking shall be with just compensation.

4. The Legislature, in order to insure continuity of State, county and local governmental operations in periods of emergency resulting from disasters caused by enemy attack, shall have the power and the immediate and continuing duty by legislation (I) to provide, prior to the occurrence of the emergency, for prompt and temporary succession to the powers and duties of public offices, of whatever nature and whether filled by election or appointment, the incumbents of which may become unavailable for carrying on the powers and duties of such offices, and (2) to adopt such other measures as may be necessary and proper for insuring the continuity of governmental operations. In the exercise of the powers hereby conferred the Legislature shall in all respects conform to the requirements of this Constitution except to the extent that in the judgment of the Legislature to do so would be 
impracticable or would admit of undue delay. Article IV, Section VI, paragraph 4 added effective December 7, I96I.

\section{SECTION VII}

I. No divorce shall be granted by the Legislature.

2. No gambling of any kind shall be authorized by the Legislature unless the specific kind, restrictions and control thereof have been heretofore submitted to, and authorized by a majority of the votes cast by, the people at a special election or shall hereafter be submitted to, and authorized by a majority of the votes cast thereon by, the legally qualified voters of the State voting at a general election, except that, without any such submission or authorization:

A. It shall be lawful for bona fide veterans, charitable, educational, religious or fraternal organizations, civic and service clubs, senior citizen associations or clubs, volunteer fire companies and first-aid or rescue squads to conduct, under such restrictions and control as shall from time to time be prescribed by the Legislature by law, games of chance of, and restricted to, the selling of rights to participate, the awarding of prizes, in the specific kind of game of chance sometimes known as bingo or lotto, played with cards bearing numbers or other designations, 5 or more in one line, the holder covering numbers as objects, similarly numbered, are drawn from a receptacle and the game being won by the person who first covers a previously designated arrangement of numbers on such a card, when the entire net proceeds of such games of chance are to be devoted to educational, charitable, patriotic, religious or public-spirited uses, and in the case of senior citizen associations or clubs to the support of such organizations, in any municipality, in which a majority of the qualified voters, voting thereon, at a general or special election as the submission thereof shall be prescribed by the Legislature by law, shall authorize the conduct of such games of chance therein;

B. It shall be lawful for the Legislature to authorize, by law, bona fide veterans, charitable, educational, religious or fraternal organizations, civic and service clubs, senior citizen associations or clubs, volunteer fire companies and firstaid or rescue squads to conduct games of chance of, and restricted to, the selling of rights to participate, and the awarding of prizes, in the specific kinds of games of chance sometimes known as raffles, conducted by the drawing for prizes or by the allotment of prizes by chance, when the entire net proceeds of such games of chance are to be devoted to educational, 
charitable, patriotic, religious or public-spirited uses, and in the case of senior citizen associations or clubs to the support of such organizations, in any municipality, in which such law shall be adopted by a majority of the qualified voters, voting thereon, at a general or special election as the submission thereof shall be prescribed by law and for the Legislature, from time to time, to restrict and control, by law, the conduct of such games of chance;

C. It shall be lawful for the Legislature to authorize the conduct of State lotteries restricted to the selling of rights to participate therein and the awarding of prizes by drawings when the entire net proceeds of any such lottery shall be for State institutions, State aid for education;

D. It shall be lawful for the Legislature to authorize by law the establishment and operation, under regulation and control by the State, of gambling houses or casinos within the boundaries, as heretofore established, of the city of Atlantic City, county of Atlantic, and to license and tax such operations and equipment used in connection therewith. Any law authorizing the establishment and operation of such gambling establishments shall provide for the State revenues derived therefrom to be applied solely for the purpose of providing funding for reductions in property taxes, rental, telephone, gas, electric, and municipal utilities charges of eligible senior citizens and disabled residents of the State, and for additional or expanded health services or benefits or transportation services or benefits to eligible senior citizens and disabled residents, in accordance with such formulae as the Legislature shall by law provide. The type and number of such casinos or gambling houses and of the gambling games which may be conducted in any such establishment shall be determined by or pursuant to the terms of the law authorizing the establishment and operation thereof;

E. It shall be lawful for the Legislature to authorize, by law, (I) the simultaneous transmission by picture of running and harness horse races conducted at racetracks located within or outside of this State, or both, to gambling houses or casinos in the city of Atlantic City and (2) the specific kind, restrictions and control of wagering at those gambling establishments on the results of those races. The State's share of revenues derived therefrom shall be applied for services to benefit eligible senior citizens as shall be provided by law; and

F. It shall be lawful for the Legislature to authorize, by law, the specific kind, 
restrictions and control of wagering on the results of live or simulcast running and harness horse races conducted within or outside of this State. The State's share of revenues derived therefrom shall be used for such purposes as shall be provided by law.

Article IV, Section VII, paragraph 2 amended effective December 3, 1998.

3. The Legislature shall not pass any bill of attainder, ex post facto law, or law impairing the obligation of contracts, or depriving a party of any remedy for enforcing a contract which existed when the contract was made.

4. To avoid improper influences which may result from intermixing in one and the same act such things as have no proper relation to each other, every law shall embrace but one object, and that shall be expressed in the title. This paragraph shall not invalidate any law adopting or enacting a compilation, consolidation, revision, or rearrangement of all or parts of the statutory law.

5. No law shall be revived or amended by reference to its title only, but the act revived, or the section or sections amended, shall be inserted at length. No act shall be passed which shall provide that any existing law, or any part thereof, shall be made or deemed a part of the act or which shall enact that any existing law, or any part thereof, shall be applicable, except by inserting it in such act.

6. The laws of this State shall begin in the following style: "Be it enacted by the Senate and General Assembly of the State of New Jersey."

7. No general law shall embrace any provision of a private, special or local character.

8. No private, special or local law shall be passed unless public notice of the intention to apply therefor, and of the general object thereof, shall have been previously given. Such notice shall be given at such time and in such manner and shall be so evidenced and the evidence thereof shall be so preserved as may be provided by law.

9. The Legislature shall not pass any private, special or local laws: (I) Authorizing the sale of any lands belonging in whole or in part to a minor or minors or other persons who may at the time be under any legal disability to act for themselves. (2) Changing the law of descent. (3) Providing for change of venue in civil or criminal causes. (4) Selecting, drawing, summoning or empaneling grand or petit jurors. (5) Creating, increasing or decreasing 
the emoluments, term or tenure rights of any public officers or employees. (6) Relating to taxation or exemption therefrom. (7) Providing for the management and control of free public schools. (8) Granting to any corporation, association or individual any exclusive privilege, immunity or franchise whatever. (9) Granting to any corporation, association or individual the right to lay down railroad tracks. (I0) Laying out, opening, altering, constructing, maintaining and repairing roads or highways. (II) Vacating any road, town plot, street, alley or public grounds. (I2) Appointing local officers or commissions to regulate municipal affairs. (13) Regulating the internal affairs of municipalities formed for local government and counties, except as otherwise in this Constitution provided. The Legislature shall pass general laws providing for the cases enumerated in this paragraph, and for all other cases which, in its judgment, may be provided for by general laws. The Legislature shall pass no special act conferring corporate powers, but shall pass general laws under which corporations may be organized and corporate powers of every nature obtained, subject, nevertheless, to repeal or alteration at the will of the Legislature.

I0. Upon petition by the governing body of any municipal corporation formed for local government, or of any county, and by vote of two-thirds of all the members of each house, the Legislature may pass private, special or local laws regulating the internal affairs of the municipality or county. The petition shall be authorized in a manner to be prescribed by general law and shall specify the general nature of the law sought to be passed. Such law shall become operative only if it is adopted by ordinance of the governing body of the municipality or county or by vote of the legally qualified voters thereof. The Legislature shall prescribe in such law or by general law the method of adopting such law, and the manner in which the ordinance of adoption may be enacted or the vote taken, as the case may be.

I I. The provisions of this Constitution and of any law concerning municipal corporations formed for local government, or concerning counties, shall be liberally construed in their favor. The powers of counties and such municipal corporations shall include not only those granted in express terms but also those of necessary or fair implication, or incident to the powers expressly conferred, or essential thereto, and not inconsistent with or prohibited by this Constitution or by law. 


\section{SECTION VIII}

I. Members of the Legislature shall, before they enter on the duties of their respective offices, take and subscribe the following oath or affirmation: "I do solemnly swear (or affirm) that I will support the Constitution of the United States and the Constitution of the State of New Jersey, and that I will faithfully discharge the duties of Senator (or member of the General Assembly) according to the best of my ability." Members-elect of the Senate or General Assembly are empowered to administer said oath or affirmation to each other.

2. Every officer of the Legislature shall, before he enters upon his duties, take and subscribe the following oath or affirmation: "I do solemnly promise and swear (or affirm) that I will faithfully, impartially and justly perform all the duties of the office of ................. to the best of my ability and understanding; that I will carefully preserve all records, papers, writings, or property entrusted to me for safekeeping by virtue of my office, and make such disposition of the same as may be required by law."

\section{ARTICLE VEXECUTIVE}

\section{SECTION I}

I. The executive power shall be vested in a Governor.

2. The Governor shall not be less than thirty years of age, and shall have been for at least twenty years a citizen of the United States, and a resident of this State seven years next before his election, unless he shall have been absent during that time on the public business of the United States or of this State.

3. No member of Congress or person holding any office or position, of profit, under this State or the United States shall be Governor. If the Governor or person administering the office of Governor shall accept any other office or position, of profit, under this State or the United States, his office of Governor shall thereby be vacated. No Governor shall be elected by the Legislature to any office during the term for which he shall have been elected Governor.

4. The Governor shall be elected by the legally qualified voters of this State. The person receiving the greatest number of votes shall be the Governor; but if two or more shall be equal and greatest in votes, one of them shall be elected Governor by the vote of a majority of all the members of both 
houses in joint meeting at the regular legislative session next following the election for Governor by the people. Contested elections for the office of Governor shall be determined in such manner as may be provided by law.

5. The term of office of the Governor shall be four years, beginning at noon of the third Tuesday in January next following his election, and ending at noon of the third Tuesday in January four years thereafter. No person who has been elected Governor for two successive terms, including an unexpired term, shall again be eligible for that office until the third Tuesday in January of the fourth year following the expiration of his second successive term.

6. In the event of a vacancy in the office of Governor resulting from the death, resignation or removal of a Governor in office, or the death of a Governor-elect, or from any other cause, the functions, powers, duties and emoluments of the office shall devolve upon the President of the Senate, for the time being, and in the event of his death, resignation or removal, then upon the Speaker of the General Assembly, for the time being; and in the event of his death, resignation or removal, then upon such officers and in such order of succession as may be provided by law; until a new Governor shall be elected and qualify.

7. In the event of the failure of the Governor-elect to qualify, or of the absence from the State of a Governor in office, or his inability to discharge the duties of his office, or his impeachment, the functions, powers, duties and emoluments of the office shall devolve upon the President of the Senate, for the time being; and in the event of his death, resignation, removal, absence, inability or impeachment, then upon the Speaker of the General Assembly, for the time being; and in the event of his death, resignation, removal, absence, inability or impeachment, then upon such officers and in such order of succession as may be provided by law; until the Governor-elect shall qualify, or the Governor in office shall return to the State, or shall no longer be unable to discharge the duties of the office, or shall be acquitted, as the case may be, or until a new Governor shall be elected and qualify.

8. Whenever a Governor-elect shall have failed to qualify within six months after the beginning of his term of office, or whenever for a period of six months a Governor in office, or person administering the office, shall have remained continuously absent from the State, or shall have been continuously unable to discharge the duties of his office by reason of mental or physical disability, the office shall be deemed vacant. Such vacancy shall be determined 
by the Supreme Court upon presentment to it of a concurrent resolution declaring the ground of the vacancy, adopted by a vote of two-thirds of all the members of each house of the Legislature, and upon notice, hearing before the Court and proof of the existence of the vacancy.

9. In the event of a vacancy in the office of Governor, a Governor shall be elected to fill the unexpired term at the general election next succeeding the vacancy, unless the vacancy shall occur within sixty days immediately preceeding a general election, in which case he shall be elected at the second succeeding general election; but no election to fill an unexpired term shall be held in any year in which a Governor is to be elected for a full term. A Governor elected for an unexpired term shall assume his office immediately upon his election.

I0. The Governor shall receive for his services a salary, which shall be neither increased nor diminished during the period for which he shall have been elected.

II. The Governor shall take care that the laws be faithfully executed. To this end he shall have power, by appropriate action or proceeding in the courts brought in the name of the State, to enforce compliance with any constitutional or legislative mandate, or to restrain violation of any constitutional or legislative power or duty, by any officer, department or agency of the State; but this power shall not be construed to authorize any action or proceeding against the Legislature.

I2. The Governor shall communicate to the Legislature, by message at the opening of each regular session and at such other times as he may deem necessary, the condition of the State, and shall in like manner recommend such measures as he may deem desirable. He may convene the Legislature, or the Senate alone, whenever in his opinion the public interest shall require. He shall be the Commander-in-Chief of all the military and naval forces of the State. He shall grant commissions to all officers elected or appointed pursuant to this Constitution. He shall nominate and appoint, with the advice and consent of the Senate, all officers for whose election or appointment provision is not otherwise made by this Constitution or by law.

13. The Governor may fill any vacancy occurring in any office during a recess of the Legislature, appointment to which may be made by the Governor with the advice and consent of the Senate, or by the Legislature in joint 
meeting. An ad interim appointment so made shall expire at the end of the next regular session of the Senate, unless a successor shall be sooner appointed and qualify; and after the end of the session no ad interim appointment to the same office shall be made unless the Governor shall have submitted to the Senate a nomination to the office during the session and the Senate shall have adjourned without confirming or rejecting it. No person nominated for any office shall be eligible for an ad interim appointment to such office if the nomination shall have failed of confirmation by the Senate.

I4. (a) When a bill has finally passed both houses, the house in which final action was taken to complete its passage shall cause it to be presented to the Governor before the close of the calendar day next following the date of the session at which such final action was taken. (b) A passed bill presented to the Governor shall become law: (I) if the Governor approves and signs it within the period allowed for his consideration; or, (2) if the Governor does not return it to the house of origin, with a statement of his objections, before the expiration of the period allowed for his consideration; or, (3) if, upon reconsideration of a bill objected to by the Governor, two-thirds of all the members of each house agree to pass the bill. (c) The period allowed for the Governor's consideration of a passed bill shall be from the date of presentation until noon of the forty-fifth day next following or, if the house of origin be in temporary adjournment on that day, the first day subsequent upon which the house reconvenes; except that: (1) if on the said forty-fifth day the Legislature is in adjournment sine die, any bill then pending the Governor's approval shall be returned, if he objects to it, at a special session held pursuant to subparagraph (d) of this paragraph; (2) any bill passed between the forty-fifth day and the tenth day preceding the expiration of the second legislative year shall be returned by the Governor, if he objects to it, not later than noon of the day next preceding the expiration of the second legislative year; (3) any bill passed within IO days preceding the expiration of the second legislative year shall become law only if the Governor signs it prior to noon of the seventh day following such expiration, or the Governor returns it to the House of origin, with a statement of his objections, and two-thirds of all members of each House agree to pass the bill prior to such expiration. (d) For the purpose of permitting the return of bills pursuant to this paragraph, a special session of the Legislature shall convene, without petition or call, for the sole purpose of acting upon bills returned by the Governor, on the forty-fifth day next following adjournment sine die of the 
regular session; or, if the second legislative year of a 2-year Legislature will expire before said forty-fifth day, then the day next preceding the expiration of the legislative year. (e) Upon receiving from the Governor a bill returned by him with his objections, the house in which it originated shall enter the objections at large in its journal or minutes and proceed to reconsider it. If, upon reconsideration, on or after the third day following its return, or the first day of a special session convened for the sole purpose of acting on such bills, two-thirds of all the members of the house of origin agree to pass the bill, it shall be sent, together with the objections of the Governor, to the other house; and if, upon reconsideration, it is approved by two-thirds of all the members of the house, it shall become a law. In all such cases the votes of each house shall be determined by yeas and nays, and the names of the persons voting for and against the bill shall be entered on the journal or minutes of each house. (f) The Governor, in returning with his objections a bill for reconsideration at any general or special session of the Legislature, may recommend that an amendment or amendments specified by him be made in the bill, and in such case the Legislature may amend and reenact the bill. If a bill be so amended and reenacted, it shall be presented again to the Governor, but shall become a law only if he shall sign it within IO days after presentation, except that any bill amended and reenacted within IO days preceding the expiration of the second legislative year shall become law only if the Governor signs it prior to noon of the seventh day following such expiration. No bill shall be returned by the Governor a second time. No bill need be read three times and no emergency resolution need be adopted for the reenactment of any bill at a special session of the Legislature. Article V, Section I, paragraph I4 amended effective December 8, 1983.

I5. If any bill presented to the Governor shall contain one or more items of appropriation of money, he may object in whole or in part to any such item or items while approving the other portions of the bill. In such case he shall append to the bill, at the time of signing it, a statement of each item or part thereof to which he objects, and each item or part so objected to shall not take effect. A copy of such statement shall be transmitted by him to the house in which the bill originated, and each item or part thereof objected to shall be separately reconsidered. If upon reconsideration, on or after the third day following said transmittal, one or more of such items or parts thereof be approved by two-thirds of all the members of each house, the same shall become a part of the law, notwithstanding the objections of the 
Governor. All the provisions of the preceding paragraph in relation to bills not approved by the Governor shall apply to cases in which he shall withhold his approval from any item or items or parts thereof contained in a bill appropriating money.

\section{SECTION II}

I. The Governor may grant pardons and reprieves in all cases other than impeachment and treason, and may suspend and remit fines and forfeitures. A commission or other body may be established by law to aid and advise the Governor in the exercise of executive clemency.

2. A system for the granting of parole shall be provided by law.

\section{SECTION III}

I. Provision for organizing, inducting, training, arming, disciplining and regulating a militia shall be made by law, which shall conform to applicable standards established for the armed forces of the United States.

2. The Governor shall nominate and appoint all general and flag officers of the militia, with the advice and consent of the Senate. All other commissioned officers of the militia shall be appointed and commissioned by the Governor according to law.

\section{SECTION IV}

I. All executive and administrative offices, departments, and instrumentalities of the State government, including the offices of Secretary of State and Attorney General, and their respective functions, powers and duties, shall be allocated by law among and within not more than twenty principal departments, in such manner as to group the same according to major purposes so far as practicable. Temporary commissions for special purposes may, however, be established by law and such commissions need not be allocated within a principal department.

2. Each principal department shall be under the supervision of the Governor. The head of each principal department shall be a single executive unless otherwise provided by law. Such single executives shall be nominated and appointed by the Governor, with the advice and consent of the Senate, to serve at the pleasure of the Governor during his term of office and until the appointment and qualification of their successors, except as herein otherwise provided with respect to the Secretary of State and the Attorney General. 
3. The Secretary of State and the Attorney General shall be nominated and appointed by the Governor with the advice and consent of the Senate to serve during the term of office of the Governor.

4. Whenever a board, commission or other body shall be the head of a principal department, the members thereof shall be nominated and appointed by the Governor with the advice and consent of the Senate, and may be removed in the manner provided by law. Such a board, commission or other body may appoint a principal executive officer when authorized by law, but the appointment shall be subject to the approval of the Governor. Any principal executive officer so appointed shall be removable by the Governor, upon notice and an opportunity to be heard.

5. The Governor may cause an investigation to be made of the conduct in office of any officer or employee who receives his compensation from the State of New Jersey, except a member, officer or employee of the Legislature or an officer elected by the Senate and General Assembly in joint meeting, or a judicial officer. He may require such officers or employees to submit to him a written statement or statements, under oath, of such information as he may call for relating to the conduct of their respective offices or employments. After notice, the service of charges and an opportunity to be heard at public hearing the Governor may remove any such officer or employee for cause. Such officer or employee shall have the right of judicial review, on both the law and the facts, in such manner as shall be provided by law.

6. No rule or regulation made by any department, officer, agency or authority of this state, except such as relates to the organization or internal management of the State government or a part thereof, shall take effect until it is filed either with the Secretary of State or in such other manner as may be provided by law. The Legislature shall provide for the prompt publication of such rules and regulations. The Legislature may review any rule or regulation to determine if the rule or regulation is consistent with the intent of the Legislature as expressed in the language of the statute which the rule or regulation is intended to implement. Upon a finding that an existing or proposed rule or regulation is not consistent with legislative intent, the Legislature shall transmit this finding in the form of a concurrent resolution to the Governor and the head of the Executive Branch agency which promulgated, or plans to promulgate, the rule or regulation. The agency shall have 30 days to amend or withdraw the existing or proposed rule or 
regulation. If the agency does not amend or withdraw the existing or proposed rule or regulation, the Legislature may invalidate that rule or regulation, in whole or in part, or may prohibit that proposed rule or regulation, in whole or in part, from taking effect by a vote of a majority of the authorized membership of each House in favor of a concurrent resolution providing for invalidation or prohibition, as the case may be, of the rule or regulation. This vote shall not take place until at least 20 calendar days after the placing on the desks of the members of each House of the Legislature in open meeting of the transcript of a public hearing held by either House on the invalidation or prohibition of the rule or regulation. Article $\mathrm{V}$, section IV, paragraph 6 amended effective December 3, 1992.

\section{ARTICLE VI JUDICIAL}

\section{SECTION I}

I. The judicial power shall be vested in a Supreme Court, a Superior Court, and other courts of limited jurisdiction. The other courts and their jurisdiction may from time to time be established, altered or abolished by law. Article VI, Section I, paragraph I amended effective December 7, I978.

\section{SECTION II}

I. The Supreme Court shall consist of a Chief Justice and six Associate Justices. Five members of the court shall constitute a quorum. When necessary, the Chief Justice shall assign the Judge or Judges of the Superior Court, senior in service, as provided by rules of the Supreme Court, to serve temporarily in the Supreme Court. In case the Chief Justice is absent or unable to serve, a presiding Justice designated in accordance with rules of the Supreme Court shall serve temporarily in his stead.

2. The Supreme Court shall exercise appellate jurisdiction in the last resort in all causes provided in this Constitution.

3. The Supreme Court shall make rules governing the administration of all courts in the State and, subject to the law, the practice and procedure in all such courts. The Supreme Court shall have jurisdiction over the admission to the practice of law and the discipline of persons admitted.

\section{SECTION III}

I. The Superior Court shall consist of such number of judges as may be authorized by law, each of whom shall exercise the powers of the court 
subject to rules of the Supreme Court. The Superior Court shall at all times consist of at least two judges who shall be assigned to sit in each of the counties of this State, and who are resident therein at the time of appointment and reappointment. Article VI, Section III, paragraph I amended effective December 7, 1978.

2. The Superior Court shall have original general jurisdiction throughout the State in all causes.

3. The Superior Court shall be divided into an Appellate Division, a Law Division and a Chancery Division, which shall include a family part. Each division shall have such other parts, consist of such number of judges, and hear such causes, as may be provided by rules of the Supreme Court. At least two judges of the Superior Court shall at all times be assigned to sit in each of the counties of the State, who at the time of their appointment and reappointment were residents of that county provided, however, that the number of judges required to reside in the county wherein they sit shall be at least equal in number to the number of judges of the county court sitting in each of the counties at the adoption of this amendment. Article VI, Section III, paragraph 3 amended effective December 8, 1983.

4. Subject to rules of the Supreme Court, the Law Division and the Chancery Division shall each exercise the powers and functions of the other division when the ends of justice so require, and legal and equitable relief shall be granted in any cause so that all matters in controversy between the parties may be completely determined. Article VI, Section IV, repealed effective December 7, 1978.

\section{SECTION V}

I. Appeals may be taken to the Supreme Court:(a) In causes determined by the appellate division of the Superior Court involving a question arising under the Constitution of the United States or this State; (b) In causes where there is a dissent in the Appellate Division of the Superior Court; (c) In capital causes; (d) On certification by the Supreme Court to the Superior Court and, where provided by rules of the Supreme Court, to the inferior courts; and (e) In such causes as may be provided by law.

2. Appeals may be taken to the Appellate Division of the Superior Court from the law and chancery divisions of the Superior Court and in such other causes as may be provided by law. Article VI, Section V, paragraphs I 
and 2 amended effective December 7, 1978.

3. The Supreme Court and the Appellate Division of the Superior Court may exercise such original jurisdiction as may be necessary to the complete determination of any cause on review.

4. Prerogative writs are superseded and, in lieu thereof, review, hearing and relief shall be afforded in the Superior Court, on terms and in the manner provided by rules of the Supreme Court, as of right, except in criminal causes where such review shall be discretionary.

\section{SECTION VI}

I. The Governor shall nominate and appoint, with the advice and consent of the Senate, the Chief Justice and associate justices of the Supreme Court, the Judges of the Superior Court, and the judges of the inferior courts with jurisdiction extending to more than one municipality; except that upon the abolition of the juvenile and domestic relations courts or family court and county district courts as provided by law, the judges of those former courts shall become the Judges of the Superior Court without nomination by the Governor or confirmation by the Senate. No nomination to such an office shall be sent to the Senate for confirmation until after 7 days' public notice by the Governor. Article VI, Section VI, paragraph I amended effective December 8, 1983.

2. The justices of the Supreme Court and the judges of the Superior Court shall each prior to his appointment have been admitted to the practice of law in this State for at least I0 years. Article VI, Section VI, paragraph 2 amended effective December 7, 1978.

3. The Justices of the Supreme Court and the Judges of the Superior Court shall hold their offices for initial terms of 7 years and upon reappointment shall hold their offices during good behavior; provided however, that, upon the abolition of the juvenile and domestic relations courts or family court and county district courts as provided by law, the judges in office in those former courts who have acquired tenure and the Judges of the Superior Court who have acquired tenure as a judge in those former courts prior to appointment to the Superior Court, shall have tenure as Judges of the Superior Court. Judges of the juvenile and domestic relations courts or family court and county district courts who have not acquired tenure as a judge of those former courts shall hold their offices for the period of their respective terms 
which remain unexpired and shall acquire tenure upon reappointment to the Superior Court. Such justices and judges shall be retired upon attaining the age of 70 years. Provisions for the pensioning of the Justices of the Supreme Court and the Judges of the Superior Court shall be made by law. Article VI, Section VI, paragraph 3 amended effective December 8, I983.

4. The Justices of the Supreme Court and the Judges of the Superior Court shall be subject to impeachment, and any judicial officer impeached shall not exercise his office until acquitted. The Judges of the Superior Court shall also be subject to removal from office by the Supreme Court for such causes and in such manner as shall be provided by law.

5. Whenever the Supreme Court shall certify to the Governor that it appears that any Justice of the Supreme Court or Judge of the Superior Court is so incapacitated as substantially to prevent him from performing his judicial duties, the Governor shall appoint a commission of three persons to inquire into the circumstances; and, on their recommendation, the Governor may retire the justice or judge from office, on pension as may be provided by law. Article VI, Section VI, paragraphs 4 and 5 amended effective December 7 , I978.

6. The Justices of the Supreme Court and the Judges of the Superior Court shall receive for their services such salaries as may be provided by law, which shall not be diminished during the term of their appointment. They shall not, while in office, engage in the practice of law or other gainful pursuit.

7. The Justices of the Supreme Court and the Judges of the Superior Court shall hold no other office or position, of profit, under this State or the United States. Any such justice or judge who shall become a candidate for an elective public office shall thereby forfeit his judicial office. Article VI, Section VI, paragraph 7 amended effective December 7, 1978.

\section{SECTION VII}

I. The Chief Justice of the Supreme Court shall be the administrative head of all the courts in the State. He shall appoint an Administrative Director to serve at his pleasure.

2. The Chief Justice of the Supreme Court shall assign Judges of the Superior Court to the Divisions and Parts of the Superior Court, and may from time to time transfer Judges from one assignment to another, as need appears. Assignments to the Appellate Division shall be for terms fixed by rules of the Supreme Court. 
3. The Clerk of the Supreme Court and the Clerk of the Superior Court shall be appointed by the Supreme Court for such terms and at such compensation as shall be provided by law.

\section{SECTION VIII}

I. a. On or before July I, I997: (I) The State shall be required to pay for certain judicial and probation costs; (2) All judicial employees and probation employees shall be employees of the State; and (3) Any judicial fees and probation fees collected shall be paid to the State Treasury. $b$. As used in this section: (I) "Judicial facility costs" means any costs borne by the counties prior to July I, I993 with regard to the operation and maintenance of facilities used by the courts or judicial employees; (2) "Probation facility costs" means any costs borne by the counties prior to July I, I993 with regard to the operation and maintenance of facilities used by probation employees; (3) "Judicial costs" means the costs incurred by the county for funding the judicial system, including but not limited to the following costs: salaries, health benefits and pension payments of all judicial employees, juror fees and library material costs, except that judicial costs shall not include costs incurred by employees of the surrogate's office or judicial facility costs; (4) "Judicial employees" means any person employed by the county prior to July I, I993 to perform judicial functions, including but not limited to employees working for the courts, and the law library and employees of the sheriff's office who act as court aides, except that employees of the surrogate's office and probation employees shall not be construed to be judicial employees; (5) "Judicial fees" means any fees or fines collected by the judiciary but shall not include sheriff's or surrogate's fees or municipal court fees or fines; (6) "Judicial functions" means any duties and responsibilities performed in providing any services and direct support necessary for the effective operation of the judicial system; (7) "Probation costs" means any costs incurred by the county for the operation of the county probation department, including but not limited to the costs of salaries, health benefits, and pension payments of probation employees but shall not include probation facility costs; (8) "Probation employees" means any person employed by a county probation department prior to July I,I993; (9) "Probation fees" means any fees or fines collected in connection with the probation of any persons. Section VIII added effective December 3, 1992. 


\section{ARTICLE VII PUBLIC OFFICERS AND EMPLOYEESSECTION I}

1. Every State officer, before entering upon the duties of his office, shall take and subscribe an oath or affirmation to support the Constitution of this State and of the United States and to perform the duties of his office faithfully, impartially and justly to the best of his ability.

2. Appointments and promotions in the civil service of the State, and of such political subdivisions as may be provided by law, shall be made according to merit and fitness to be ascertained, as far as practicable, by examination, which, as far as practicable, shall be competitive; except that preference in appointments by reason of active service in any branch of the military or naval forces of the United States in time of war may be provided by law.

3. Any compensation for services or any fees received by any person by virtue of an appointive State office or position, in addition to the annual salary provided for the office or position, shall immediately upon receipt be paid into the treasury of the State, unless the compensation or fees shall be allowed or appropriated to him by law.

4. Any person before or after entering upon the duties of any public office, position or employment in this State may be required to give bond as may be provided by law.

5. The term of office of all officers elected or appointed pursuant to the provisions of this Constitution, except as herein otherwise provided, shall commence on the day of the date of their respective commissions; but no commission for any office shall bear date prior to the expiration of the term of the incumbent of said office.

6. The State Auditor shall be appointed by the Senate and General Assembly in joint meeting for a term of five years and until his successor shall be appointed and qualified. It shall be his duty to conduct post-audits of all transactions and accounts kept by or for all departments, offices and agencies of the State government, to report to the Legislature or to any committee thereof as shall be required by law, and to perform such other similar or related duties as shall, from time to time, be required of him by law.

\section{SECTION II}

1. County prosecutors shall be nominated and appointed by the Governor with the advice and consent of the Senate. Their term of office shall be five years, and they shall serve until the appointment and qualification of their 
respective successors.

2. County clerks, surrogates and sheriffs shall be elected by the people of their respective counties at general elections. The term of office of county clerks and surrogates shall be five years, and of sheriffs three years. Whenever a vacancy shall occur in any such office it shall be filled in the manner to be provided by law.

\section{SECTION III}

1. The Governor and all other State officers, while in office and for two years thereafter, shall be liable to impeachment for misdemeanor committed during their respective continuance in office.

2. The General Assembly shall have the sole power of impeachment by vote of a majority of all the members. All impeachments shall be tried by the Senate, and members, when sitting for that purpose, shall be on oath or affirmation "truly and impartially to try and determine the charge in question according to the evidence". No person shall be convicted without the concurrence of two-thirds of all the members of the Senate. When the Governor is tried, the Chief Justice of the Supreme Court shall preside and the President of the Senate shall not participate in the trial.

3. Judgment in cases of impeachment shall not extend further than to removal from office, and to disqualification to hold and enjoy any public office of honor, profit or trust in this State; but the person convicted shall nevertheless be liable to indictment, trial and punishment according to law.

\section{ARTICLE VIII TAXATION AND FINANCE SECTION I}

1. (a) Property shall be assessed for taxation under general laws and by uniform rules. All real property assessed and taxed locally or by the State for allotment and payment to taxing districts shall be assessed according to the same standard of value, except as otherwise permitted herein, and such real property shall be taxed at the general tax rate of the taxing district in which the property is situated, for the use of such taxing district. (b) The Legislature shall enact laws to provide that the value of land, not less than 5 acres in area, which is determined by the assessing officer of the taxing jurisdiction to be actively devoted to agricultural or horticultural use and to have been so devoted for at least the 2 successive years immediately preceding the tax year in issue, shall, for local tax purposes, on application of the owner, be 
that value which such land has for agricultural or horticultural use. Any such laws shall provide that when land which has been valued in this manner for local tax purposes is applied to a use other than for agriculture or horticulture it shall be subject to additional taxes in an amount equal to the difference, if any, between the taxes paid or payable on the basis of the valuation and the assessment authorized hereunder and the taxes that would have been paid or payable had the land been valued and assessed as otherwise provided in this Constitution, in the current year and in such of the tax years immediately preceding, not in excess of 2 such years in which the land was valued as herein authorized. Such laws shall also provide for the equalization of assessments of land valued in accordance with the provisions hereof and for the assessment and collection of any additional taxes levied thereupon and shall include such other provisions as shall be necessary to carry out the provisions of this amendment. Article VIII, Section I, paragraph I amended effective December 5, 1963.

2. Exemption from taxation may be granted only by general laws. Until otherwise provided by law all exemptions from taxation validly granted and now in existence shall be continued. Exemptions from taxation may be altered or repealed, except those exempting real and personal property used exclusively for religious, educational, charitable or cemetery purposes, as defined by law, and owned by any corporation or association organized and conducted exclusively for one or more of such purposes and not operating for profit.

3. Any citizen and resident of this State now or hereafter honorably discharged or released under honorable circumstances from active service, in time of war or other emergency as, from time to time, defined by the Legislature, in any branch of the Armed Forces of the United States shall be entitled, annually to a deduction from the amount of any tax bill for taxes on real and personal property, or both, including taxes attributable to a residential unit held by a stockholder in a cooperative or mutual housing corporation, in the sum of $\$ 50.00$ or if the amount of any such tax bill shall be less than $\$ 50.00$, to a cancellation thereof, which deduction or cancellation shall not be altered or repealed. Any person hereinabove described who has been or shall be declared by the United States Veterans Administration, or its successor, to have a service-connected disability, shall be entitled to such further deduction from taxation as from time to time may be provided by law. The surviving spouse of any citizen and resident of this State who has met or shall meet his or her death on active duty in time of war or of other 
emergency as so defined in any such service shall be entitled, during her widowhood or his widowerhood, as the case may be, and while a resident of this State, to the deduction or cancellation in this paragraph provided for honorably discharged veterans and to such further deduction as from time to time may be provided by law. The surviving spouse of any citizen and resident of this State who has had or shall hereafter have active service in time of war or of other emergency as so defined in any branch of the Armed Forces of the United States and who died or shall die while on active duty in any branch of the Armed Forces of the United States, or who has been or may hereafter be honorably discharged or released under honorable circumstances from active service in time or war or of other emergency as so defined in any branch of the Armed Forces of the United States shall be entitled, during her widowhood or his widowerhood, as the case may be, and while a resident of this State, to the deduction or cancellation in this paragraph provided for honorably discharged veterans and to such further deductions as from time to time may be provided by law. Article VIII, Section I, paragraph 3 amended effective December 8, 1988.

4. The Legislature may, from time to time, enact laws granting an annual deduction, from the amount of any tax bill for taxes on the real property, and from taxes attributable to a residential unit in a cooperative or mutual housing corporation, of any citizen and resident of this State of the age of 65 or more years, or any citizen and resident of this State less than 65 years of age who is permanently and totally disabled according to the provisions of the Federal Social Security Act, residing in a dwelling house owned by him which is a constituent part of such real property, or residing in a dwelling house owned by him which is assessed as real property but which is situated on land owned by another or others, or residing as tenant-shareholder in a cooperative or mutual housing corporation, but no such deduction shall be in excess of \$160.00 with respect to any year prior to I98I, \$200.00 per year in I98I, $\$ 225.00$ per year in I982, and $\$ 250.00$ per year in I983 and any year thereafter and such deduction shall be restricted to owners having an income not in excess of $\$ 5,000.00$ per year with respect to any year prior to I98I, $\$ 8,000.00$ per year in I98I, $\$ 9,000.00$ per year in I982, and $\$ 10,000.00$ per year in 1983 and any year thereafter, exclusive of benefits under any one of the following: a. The Federal Social Security Act and all amendments and supplements thereto; b. Any other program of the federal government or pursuant to any other federal law which provides benefits in 
whole or in part in lieu of benefits referred to in, or for persons excluded from coverage under, a. hereof including but not limited to the Federal Railroad Retirement Act and federal pension, disability and retirement programs; or c. Pension, disability or retirement programs of any state or its political subdivisions, or agencies thereof, for persons not covered under a. hereof; provided, however, that the total amount of benefits to be allowed exclusion by any owner under b. or $c$. hereof shall not be in excess of the maximum amount of benefits payable to, and allowable for exclusion by, an owner in similar circumstances under a. hereof. The surviving spouse of a deceased citizen and resident of the State who during his or her life received a deduction pursuant to this paragraph shall be entitled, so long as he or she shall remain unmarried and a resident of the same dwelling house situated on the same land with respect to which said deduction was granted, to the same deduction, upon the same conditions, with respect to the same real property or with respect to the same dwelling house which is situated on land owned by another or others, or with respect to the same cooperative or mutual housing corporation, notwithstanding that said surviving spouse is under the age of 65 and is not permanently and totally disabled, provided that said surviving spouse is 55 years of age or older. Any such deduction when so granted by law shall be granted so that it will not be in addition to any other deduction or exemption, except a deduction granted under authority of paragraph 3 of this section, to which the said citizen and resident may be entitled, but said citizen and resident may receive in addition any homestead rebate or credit provided by law. The State shall annually reimburse each taxing district in an amount equal to one-half of the tax loss to the district resulting from the allowance of tax deductions pursuant to this paragraph. Article VIII, Section I, paragraph 4 amended effective December 8, I988.

5. The Legislature may adopt a homestead statute which entitles homeowners, residential tenants and net lease residential tenants to a rebate or a credit of a sum of money related to property taxes paid by or allocable to them at such rates and subject to such limits as may be provided by law. Such rebates or credits may include a differential rebate or credit to citizens and residents who are of the age of 65 or more years, or less than 65 years of age who are permanently and totally disabled according to the provisions of the Federal Social Security Act, or are 55 years of age or more and the surviving spouse of a deceased citizen or resident of this State who during his lifetime received, or who, upon the adoption of this amendment and the enactment of 
implementing legislation, would have been entitled to receive a rebate or credit related to property taxes. Article VIII, Section I, paragraph 5 amended effective December 2, 1976.

6. The Legislature may enact general laws under which municipalities may adopt ordinances granting exemptions or abatements from taxation on buildings and structures in areas declared in need of rehabilitation in accordance with statutory criteria, within such municipalities and to the land comprising the premises upon which such buildings or structures are erected and which is necessary for the fair enjoyment thereof. Such exemptions shall be for limited periods of time as specified by law, but not in excess of 5 years. Article VIII, Section I, paragraph 6 added effective December 4, 1975.

7. No tax shall be levied on personal incomes of individuals, estates and trusts of this State unless the entire net receipts therefrom shall be received into the treasury, placed in a perpetual fund and be annually appropriated, pursuant to formulas established from time to time by the Legislature, to the several counties, municipalities and school districts of this State exclusively for the purpose of reducing or offsetting property taxes. In no event, however, shall a tax so levied on personal incomes be levied on payments received under the federal Social Security Act, the federal Railroad Retirement Act, or any federal law which substantially reenacts the provisions of either of those laws. Article VIII, Section I, paragraph 7 amended effective December 6, 1984 .

\section{SECTION II}

I. The credit of the State shall not be directly or indirectly loaned in any case.

2. No money shall be drawn from the State treasury but for appropriations made by law. All moneys for the support of the State government and for all other State purposes as far as can be ascertained or reasonably foreseen, shall be provided for in one general appropriation law covering one and the same fiscal year; except that when a change in the fiscal year is made, necessary provision may be made to effect the transition. No general appropriation law or other law appropriating money for any State purpose shall be enacted if the appropriation contained therein, together with all prior appropriations made for the same fiscal period, shall exceed the total amount of revenue on hand and anticipated which will be available to meet such appropriations 
during such fiscal period, as certified by the Governor.

3. The Legislature shall not, in any manner, create in any fiscal year a debt or debts, liability or liabilities of the State, which together with any previous debts or liabilities shall exceed at any time one per centum of the total amount appropriated by the general appropriation law for that fiscal year, unless the same shall be authorized by a law for some single object or work distinctly specified therein. Regardless of any limitation relating to taxation in this Constitution, such law shall provide the ways and means, exclusive of loans, to pay the interest of such debt or liability as it falls due, and also to pay and discharge the principal thereof within thirty-five years from the time it is contracted; and the law shall not be repealed until such debt or liability and the interest thereon are fully paid and discharged. Except as hereinafter provided, no such law shall take effect until it shall have been submitted to the people at a general election and approved by a majority of the legally qualified voters of the State voting thereon. No voter approval shall be required for any such law authorizing the creation of a debt or debts in a specified amount or an amount to be determined in accordance with such law for the refinancing of all or a portion of any outstanding debts or liabilities of the State heretofore or hereafter created, so long as such law shall require that the refinancing provide a debt service savings determined in a manner to be provided in such law and that the proceeds of such debt or debts and any investment income therefrom shall be applied to the payment of the principal of, any redemption premium on, and interest due and to become due on such debts or liabilities being refinanced on or prior to the redemption date or maturity date thereof, together with the costs associated with such refinancing. All money to be raised by the authority of such law shall be applied only to the specific object stated therein, and to the payment of the debt thereby created. This paragraph shall not be construed to refer to any money that has been or may be deposited with this State by the government of the United States. Nor shall anything in this paragraph contained apply to the creation of any debts or liabilities for purposes of war, or to repel invasion, or to suppress insurrection or to meet an emergency caused by disaster or act of God. Article VIII, Section II, paragraph 3 amended effective December 8, 1983.

4. There shall be credited to a special account in the General Fund for the State fiscal year in which the amendment to this paragraph is approved by 
the voters an amount equivalent to the revenue derived from $\$ 0.025$ per gallon from the tax imposed on the sale of motor fuels pursuant to chapter 39 of Title 54 of the Revised Statutes, and an amount equivalent to the revenue derived from $\$ 0.07$ per gallon from the tax shall be credited to the account in each of the first two State fiscal years commencing after the approval of the amendment to this paragraph by the voters, and an amount equivalent to the revenue derived from $\$ 0.08$ per gallon from the tax shall be credited to the account in the third State fiscal year commencing after the approval of the amendment to this paragraph by the voters, and an amount equivalent to the revenue derived from $\$ 0.09$ per gallon from the tax shall be credited to the account in the fourth State fiscal year commencing after the approval of the amendment to this paragraph by the voters and annually thereafter; provided, however, the dedication and use of such revenues as provided in this paragraph shall be subject and subordinate to (a) all appropriations of revenues from such taxes made by laws enacted on or before December 6, 1984 in accordance with Article VIII, Section II, paragraph 3 of the State Constitution in order to provide the ways and means to pay the principal and interest on bonds of the State presently outstanding or authorized to be issued under such laws or (b) any other use of those revenues enacted into law on or before December 6, I984. These amounts shall be appropriated from time to time by the Legislature, only for the purposes of paying or financing the cost of planning, acquisition, engineering, construction, reconstruction, repair and rehabilitation of the transportation system in this State and it shall not be competent for the Legislature to borrow, appropriate or use these amounts or any part thereof for any other purpose, under any pretense whatever. Article VIII, Section II, paragraph 4 added effective December 6, 1984; amended effective December 7, 1995.

5. (a) With respect to any provision of a law enacted on and after January 17, 1996, and with respect to any rule or regulation issued pursuant to a law originally adopted after July I, I996, and except as otherwise provided herein, any provision of such law, or of such rule or regulation issued pursuant to a law, which is determined in accordance with this paragraph to be an unfunded mandate upon boards of education, counties, or municipalities because it does not authorize resources, other than the property tax, to offset the additional direct expenditures required for the implementation of the law or rule or regulation, shall, upon such determination cease to be mandatory 
in its effect and expire. A law or rule or regulation issued pursuant to a law that is determined to be an unfunded mandate shall not be considered to establish a standard of care for the purpose of civil liability. (b) The Legislature shall create by law a Council on Local Mandates. The Council shall resolve any dispute regarding whether a law or rule or regulation issued pursuant to a law constitutes an unfunded mandate. The Council shall consist of nine public members appointed as follows: four members to be appointed by the Governor; one member to be appointed by the President of the Senate; one member to be appointed by the Speaker of the General Assembly; one member to be appointed by the minority leader of the Senate; one member to be appointed by the minority leader of the General Assembly; and one member to be appointed by the Chief Justice of the New Jersey Supreme Court. Of the members appointed by the Governor, at least two shall be appointed from a list of six willing nominees submitted by the chairman of the political party whose candidate for Governor received the second largest number of votes at the most recent gubernatorial general election. The decisions of the Council shall be political and not judicial determinations. (c) Notwithstanding anything in this paragraph to the contrary, the following categories of laws or rules or regulations issued pursuant to a law, shall not be considered unfunded mandates: (I) those which are required to comply with federal laws or rules or to meet eligibility standards for federal entitlements; (2) those which are imposed on both government and non-government entities in the same or substantially similar circumstances; (3) those which repeal, revise or ease an existing requirement or mandate or which reapportion the costs of activities between boards of education, counties, and municipalities; (4) those which stem from failure to comply with previously enacted laws or rules or regulations issued pursuant to a law; (5) those which implement the provisions of this Constitution; and (6) laws which are enacted after a public hearing, held after public notice that unfunded mandates will be considered, for which a fiscal analysis is available at the time of the public hearing and which, in addition to complying with all other constitutional requirements with regard to the enactment of laws, are passed by $3 / 4$ affirmative vote of the members of each House of the Legislature. Article VIII, Section II, paragraph 5 added effective December 7, 1995.

6. There shall be credited annually to a special account in the General Fund an amount equivalent to $4 \%$ of the revenue annually derived from the tax 
imposed pursuant to the "Corporation Business Tax Act (I945)," P.L.I945, c.I62 (C.54:I0A-I et seq.), as amended and supplemented, or any other State law of similar effect. The amount annually credited pursuant to this paragraph shall be dedicated and shall be appropriated from time to time by the Legislature only for the following purposes: paying or financing costs incurred by the State for the remediation of discharges of hazardous substances, which costs may include performing necessary operation and maintenance activities relating to remedial actions and costs incurred for providing alternative sources of public or private water supplies, when a water supply has been, or is suspected of being, contaminated by a hazardous substance discharge; providing funding, including the provision of loans or grants, for the upgrade, replacement, or closure of underground storage tanks that store or were used to store hazardous substances, and for the costs of remediating any discharge therefrom; and for paying or financing the cost of water quality point and nonpoint source pollution monitoring, watershed based water resource planning and management, and nonpoint source pollution prevention projects. It shall not be competent for the Legislature, under any pretense whatever, to borrow, appropriate, or use the amount credited to the special account pursuant to this paragraph, or any portion thereof, for any purpose or in any manner other than as enumerated in this paragraph. It shall not be competent for the Legislature, under any pretense whatever, to borrow, appropriate, or use the amount credited to the special account pursuant to this paragraph, or any portion thereof, for the payment of the principal or interest on any general obligation bond that was approved by the voters prior to this paragraph becoming part of this Constitution. (a) A minimum of one-sixth of the amount annually credited pursuant to this paragraph, or a minimum of an amount equal to $\$ 5,000,000.00$ per year, whichever is less, shall be dedicated, and shall be appropriated from time to time by the Legislature, only for paying or financing the cost of water quality point and nonpoint source pollution monitoring, watershed based water resource planning and management, and nonpoint source pollution prevention projects. (b) A minimum of one-third of the amount annually credited pursuant to this paragraph shall be dedicated, and shall be appropriated from time to time by the Legislature, only for providing funding, including the provision of loans or grants, for the upgrade, replacement, or closure of underground storage tanks that store or were used to store hazardous substances, and for the costs of remediating any 
discharge therefrom, except that the dedication of moneys pursuant to this subparagraph (b) shall expire on December 3I, 2008 and may thereafter be dedicated and appropriated from time to time by the Legislature for any of the purposes authorized pursuant to subparagraphs (a), (b), or (c) of this paragraph. All moneys derived from repayments of any loan issued from the amount dedicated pursuant to this subparagraph (b) shall be dedicated, and shall be appropriated from time to time by the Legislature, only for the purposes authorized pursuant to this subparagraph (b). The dedication of moneys derived from loan repayments shall not expire. No moneys appropriated pursuant to this subparagraph (b) may be expended on any direct or indirect administrative costs of the State or any of its departments, agencies, or authorities. No moneys appropriated pursuant to this subparagraph (b) may be expended on any upgrade, replacement, or closure of any underground storage tank, or for the remediation of any discharge therefrom, for any underground storage tank owned by the State or any of its departments, agencies, or authorities. (c) A minimum of one-half of the amount annually credited pursuant to this paragraph shall be dedicated, and shall be appropriated from time to time by the Legislature, only for paying or financing costs incurred by the State for the remediation of discharges of hazardous substances, which costs may include performing necessary operation and maintenance activities relating to remedial actions and costs incurred for providing alternative sources of public or private water supplies, when a water supply has been, or is suspected of being, contaminated by a hazardous substance discharge. No moneys appropriated pursuant to this subparagraph (c) may be expended for any indirect administrative costs of the State, its departments, agencies, or authorities. No more than nine percent of the moneys annually credited pursuant to this paragraph, which shall be taken from the amount dedicated pursuant to this subparagraph (c), may be expended for any direct program administrative costs of the State, its departments, agencies, or authorities. If the Legislature dedicates for the purposes of this subparagraph (c) any moneys above the minimum that is required to be dedicated pursuant to this subparagraph (c), those moneys may not be expended for any direct or indirect administrative costs of the State, its departments, agencies, or authorities. Article VIII, Section II, paragraph 6, added effective December 5, 1996.

7. (a) Commencing July I, I999, there shall be credited in each State fiscal year, until June 30, 2009, to a special account in the General Fund 
$\$ 98,000,000$ from the State revenue annually collected from the State tax imposed under the "Sales and Use Tax Act," P.L.I966, c.30 (C.54:32B-I et seq.), as amended and supplemented, or from any other State law of similar effect. The dedication and use of those moneys credited pursuant to this subparagraph shall be subject and subordinate to (I) all appropriations of revenues from taxes made by laws enacted prior to the effective date of this paragraph in accordance with Article VIII, Section II, paragraph 3 of the State Constitution in order to provide the ways and means to pay the principal and interest on bonds of the State presently outstanding or authorized to be issued under those laws, or (2) any other use of those revenues enacted into law prior to the effective date of this paragraph. The amount credited each State fiscal year pursuant to this subparagraph shall be dedicated and shall be appropriated from time to time by the Legislature only to: provide funding, including loans or grants, for the acquisition and development of lands for recreation and conservation purposes, for the preservation of farmland for agricultural or horticultural use and production, and for historic preservation; and satisfy any payments relating to bonds, notes, or other obligations, including refunding bonds, issued by an authority or similar entity established by law to provide funding, including loans and grants, for the acquisition and development of lands for recreation and conservation purposes, for the preservation of farmland for agricultural or horticultural use and production, and for historic preservation. (b) Commencing July I, 2009 and ending June 30, 2029, there shall be credited in each State fiscal year to a special account in the General Fund from the State revenue annually collected from the State tax imposed under the "Sales and Use Tax Act," P.L.I966, c.30 (C.54:32B-I et seq.), as amended and supplemented, or from any other State law of similar effect, the lesser of $\$ 98,000,000$ or the amount necessary in each State fiscal year to satisfy any payments relating to bonds, notes, or other obligations, including refunding bonds, issued by an authority or similar entity established by law to provide funding, including loans and grants, for the acquisition and development of lands for recreation and conservation purposes, for the preservation of farmland for agricultural or horticultural use and production, and for historic preservation. The dedication and use of those moneys credited pursuant to this subparagraph shall be subject and subordinate to (I) all appropriations of revenues from taxes made by laws enacted prior to the effective date of this paragraph in accordance with Article VIII, Section II, paragraph 3 of the State Constitution in order to provide the ways and means to pay the principal and interest on bonds of 
the State presently outstanding or authorized to be issued under those laws, or (2) any other use of those revenues enacted into law prior to the effective date of this paragraph. The amount credited each State fiscal year pursuant to this subparagraph shall be dedicated and shall be appropriated from time to time by the Legislature only to satisfy any payments relating to bonds, notes, or other obligations, including refunding bonds, issued by an authority or similar entity established by law to provide funding, including loans and grants, for the acquisition and development of lands for recreation and conservation purposes, for the preservation of farmland for agricultural or horticultural use and production, and for historic preservation. (c) Moneys credited to the special account pursuant to this paragraph shall not be used for (I) payments related to bonds, notes, or other obligations which in aggregate principal amount exceed $\$ 1,000,000,000$ plus costs of issuance; or (2) payments relating to bonds, notes, or other obligations, except refunding bonds, issued after June 30, 2009. (d) The authority or similar entity established by law as described in this paragraph shall consist of members appointed by the Governor and of members appointed by the Legislature. (e) All moneys derived from repayments of any loan issued from the amounts dedicated pursuant to subparagraph (a) of this paragraph, and all income derived from the investment of moneys in the special account established pursuant to this paragraph, shall be credited to that special account, and shall be dedicated and shall be appropriated from time to time by the Legislature only for the purpose of providing funding, including loans or grants, for the acquisition and development of lands for recreation and conservation purposes, for the preservation of farmland for agricultural or horticultural use and production, and for historic preservation. Notwithstanding any provision of this paragraph to the contrary, the dedication of moneys derived from loan repayments and investments shall not expire. (f) It shall not be competent for the Legislature, under any pretense whatever, to borrow, appropriate, or use the amounts credited to the special account established pursuant to this paragraph, or any portion thereof, for any purpose or in any manner other than as enumerated in this paragraph.

Article VIII, Section II, paragraph 7 added effective December 3, 1998.

\section{SECTION III}

I. The clearance, replanning, development or redevelopment of blighted areas shall be a public purpose and public use, for which private property may be taken or acquired. Municipal, public or private corporations may be 
authorized by law to undertake such clearance, replanning, development or redevelopment; and improvements made for these purposes and uses, or for any of them, may be exempted from taxation, in whole or in part, for a limited period of time during which the profits of and dividends payable by any private corporation enjoying such tax exemption shall be limited by law. The conditions of use, ownership, management and control of such improvements shall be regulated by law.

2. No county, city, borough, town, township or village shall hereafter give any money or property, or loan its money or credit, to or in aid of any individual, association or corporation, or become security for, or be directly or indirectly the owner of, any stock or bonds of any association or corporation.

3. No donation of land or appropriation of money shall be made by the State or any county or municipal corporation to or for the use of any society, association or corporation whatever.

\section{SECTION IV}

I. The Legislature shall provide for the maintenance and support of a thorough and efficient system of free public schools for the instruction of all the children in the State between the ages of five and eighteen years.

2. The fund for the support of free public schools, and all money, stock and other property, which may hereafter be appropriated for that purpose, or received into the treasury under the provisions of any law heretofore passed to augment the said fund, shall be securely invested, and remain a perpetual fund; and the income thereof, except so much as it may be judged expedient to apply to an increase of the capital, shall be annually appropriated to the support of free public schools, and for the equal benefit of all the people of the State; and it shall not be competent, except as hereinafter provided, for the Legislature to borrow, appropriate or use the said fund or any part thereof for any other purpose, under any pretense whatever. The bonds of any school district of this State, issued according to law, shall be proper and secure investments for the said fund and, in addition, said fund, including the income therefrom and any other moneys duly appropriated to the support of free public schools may be used in such manner as the Legislature may provide by law to secure the payment of the principal of or interest on bonds or notes issued for school purposes by counties, municipalities or school districts or for the payment or purchase of any such bonds or notes or any claims for 
interest thereon. Article VIII, Section IV, paragraph 2 amended effective December 4, 1958.

3. The Legislature may, within reasonable limitations as to distance to be prescribed, provide for the transportation of children within the ages of five to eighteen years inclusive to and from any school.

\section{SECTION V}

I. No lands that were formerly tidal flowed, but which have not been tidal flowed at any time for a period of 40 years, shall be deemed riparian lands, or lands subject to a riparian claim, and the passage of that period shall be a good and sufficient bar to any such claim, unless during that period the State has specifically defined and asserted such a claim pursuant to law. This section shall apply to lands which have not been tidal flowed at any time during the 40 years immediately preceding adoption of this amendment with respect to any claim not specifically defined and asserted by the State within I year of the adoption of this amendment. Article VIII, Section V, paragraph I added effective December 3, I98I.

\section{ARTICLE IX AMENDMENTS}

I. Any specific amendment or amendments to this Constitution may be proposed in the Senate or General Assembly. At least twenty calendar days prior to the first vote thereon in the house in which such amendment or amendments are first introduced, the same shall be printed and placed on the desks of the members of each house. Thereafter and prior to such vote a public hearing shall be held thereon. If the proposed amendment or amendments or any of them shall be agreed to by three-fifths of all the members of each of the respective houses, the same shall be submitted to the people. If the same or any of them shall be agreed to by less then threefifths but nevertheless by a majority of all the members of each of the respective houses, such proposed amendment or amendments shall be referred to the Legislature in the next legislative year; and if in that year the same or any of them shall be agreed to by a majority of all the members of each of the respective houses, then such amendment or amendments shall be submitted to the people.

2. The proposed amendment or amendments shall be entered on the journal of each house with the yeas and nays of the members voting thereon.

3. The Legislature shall cause the proposed amendment or amendments to 
be published at least once in one or more newspapers of each county, if any be published therein, not less than three months prior to submission to the people.

4. The proposed amendment or amendments shall then be submitted to the people at the next general election in the manner and form provided by the Legislature.

5. If more than one amendment be submitted, they shall be submitted in such manner and form that the people may vote for or against each amendment separately and distinctly.

6. If the proposed amendment or amendments or any of them shall be approved by a majority of the legally qualified voters of the State voting thereon, the same shall become part of the Constitution on the thirtieth day after the election, unless otherwise provided in the amendment or amendments.

7. If at the election a proposed amendment shall not be approved, neither such proposed amendment nor one to effect the same or substantially the same change in the Constitution shall be submitted to the people before the third general election thereafter.

\section{ARTICLE X GENERAL PROVISIONS}

I. The seal of the State shall be kept by the Governor, or person administering the office of Governor, and used by him officially, and shall be called the Great Seal of the State of New Jersey.

2. All grants and commissions shall be in the name and by the authority of the State of New Jersey, sealed with the Great Seal, signed by the Governor, or person administering the office of Governor, and countersigned by the Secretary of State, and shall run thus: "The State of New Jersey, to ................, Greeting”.

3. All writs shall be in the name of the State. All indictments shall conclude: "against the peace of this State, the government and dignity of the same".

4. Wherever in this Constitution the term "person", "persons", "people" or any personal pronoun is used, the same shall be taken to include both sexes.

5. Except as herein otherwise provided, this Constitution shall take effect on the first day of January in the year of our Lord one thousand nine hundred and forty-eight. 


\section{ARTICLE XISCHEDULE SECTION I}

I. This Constitution shall supersede the Constitution of one thousand eight hundred and forty-four as amended.

2. The Legislature shall enact all laws necessary to make this Constitution fully effective.

3. All law, statutory and otherwise, all rules and regulations of administrative bodies and all rules of courts in force at the time this Constitution or any Article thereof takes effect shall remain in full force until they expire or are superseded, altered or repealed by this Constitution or otherwise.

4. Except as otherwise provided by this Constitution, all writs, actions, judgments, decrees, causes of action, prosecutions, contracts, claims and rights of individuals and of bodies corporate, and of the State, and all charters and franchises shall continue unaffected notwithstanding the taking effect of any Article of this Constitution.

5. All indictments found before the taking effect of this Constitution or any Article may be proceeded upon. After the taking effect thereof, indictments for crime and complaints for offenses committed prior thereto may be found, made and proceeded upon in the courts having jurisdiction thereof.

\section{SECTION II}

I. The first Legislature under this Constitution shall meet on the second Tuesday in January, in the year one thousand nine hundred and forty-eight.

2. Each member of the General Assembly, elected at the election in the year one thousand nine hundred and forty-seven, shall hold office for a term beginning at noon of the second Tuesday in January in the year one thousand nine hundred and forty-eight and ending at noon of the second Tuesday in January in the year one thousand nine hundred and fifty. Each member of the General Assembly elected thereafter shall hold office for the term provided by this Constitution.

3. Each member of the Senate elected in the years one thousand nine hundred and forty-five and one thousand nine hundred and forty-six shall hold office for the term for which he was elected. Each member of the Senate elected in the year one thousand nine hundred and forty-seven shall hold office for a term of four years beginning at noon of the second Tuesday in January 
following his election. The seats in the Senate which would have been filled in the years hereinafter designated had this Constitution not been adopted shall be filled by election as follows: of those seats which would have been filled by election in the year one thousand nine hundred and forty-eight, three seats, as chosen by the Senate in the year one thousand nine hundred and forty-eight, shall be filled by election in that year for terms of five years, and three, as so chosen, shall be filled by election in that year for terms of three years, and those seats which would have been filled by election in the year one thousand nine hundred and forty-nine shall be filled by election in that year for terms of four years, so that eleven seats in the Senate shall be filled by election in the year one thousand nine hundred and fifty-one and every fourth year thereafter for terms of four years, and the members of the Senate so elected and their successors shall constitute one class to be elected as prescribed in paragraph 2 of Section II of Article IV of this Constitution, and ten seats shall be filled by election in the year one thousand nine hundred and fifty-three and every fourth year thereafter for terms of four years, and the members of the Senate so elected and their successors shall constitute the other class to be elected as prescribed in said paragraph of this Constitution.

4. The provisions of Paragraph I of Section V of Article IV of this Constitution shall not prohibit the nomination, election or appointment of any member of the Senate or General Assembly first organized under this Constitution, to any State civil office or position created by this Constitution or created during his first term as such member.

\section{SECTION III}

I. A Governor shall be elected for a full term at the general election to be held in the year one thousand nine hundred and forty-nine and every fourth year thereafter.

2. The taking effect of this Constitution or any provision thereof shall not of itself affect the tenure, term, status or compensation of any person then holding any public office, position or employment in this State, except as provided in this Constitution. Unless otherwise specifically provided in this Constitution, all constitutional officers in office at the time of its adoption shall continue to exercise the authority of their respective offices during the term for which they shall have been elected or appointed and until the qualification of their successors respectively. Upon the taking effect of this 
Constitution all officers of the militia shall retain their commissions subject to the provisions of Article V, Section III.

3. The Legislature, in compliance with the provisions of this Constitution, shall prior to the first day of July, one thousand nine hundred and fortynine, and may from time to time thereafter, allocate by law the executive and administrative offices, departments and instrumentalities of the State government among and within the principal departments. If such allocation shall not have been completed within the time limited, the Governor shall call a special session of the Legislature to which he shall submit a plan or plans for consideration to complete such allocation; and no other matters shall be considered at such session.

\section{SECTION IV}

I. Subsequent to the adoption of this Constitution the Governor shall nominate and appoint, with the advice and consent of the Senate, a Chief Justice and six Associate Justices of the new Supreme Court from among the persons then being the Chancellor, the Chief Justice and Associate Justices of the old Supreme Court, the Vice Chancellors and Circuit Court Judges. The remaining judicial officers enumerated and such Judges of the Court of Errors and Appeals as have been admitted to the practice of law in this State for at least ten years, and are in office on the adoption of the Constitution, shall constitute the Judges of the Superior Court. The Justices of the new Supreme Court and the Judges of the Superior Court so designated shall hold office each for the period of his term which remains unexpired at the time the Constitution is adopted; and if reappointed he shall hold office during good behavior. No Justice of the new Supreme Court or Judge of the Superior Court shall hold his office after attaining the age of seventy years, except, however, that such Justice or Judge may complete the period of his term which remains unexpired at the time the Constitution is adopted.

2. The Judges of the Courts of Common Pleas shall constitute the Judges of the County Courts, each for the period of his term which remains unexpired at the time the Judicial Article of this Constitution takes effect.

3. The Court of Errors and Appeals, the present Supreme Court, the Court of Chancery, the Prerogative Court and the Circuit Courts shall be abolished when the Judicial Article of this Constitution takes effect; and all their

jurisdiction, functions, powers and duties shall be transferred to and divided 
between the new Supreme Court and the Superior Court according as jurisdiction is vested in each of them under this Constitution.

4. Except as otherwise provided in this Constitution and until otherwise provided by law, all courts now existing in this State, other than those abolished in paragraph 3 hereof, shall continue as if this Constitution had not been adopted, provided, however, that when the Judicial Article of this Constitution takes effect, the jurisdiction, powers and functions of the Court of Common Pleas, Orphans' Court, Court of Oyer and Terminer, Court of Quarter Sessions and Court of Special Sessions of each county, the judicial officers, clerks and employees thereof, and the causes pending therein and their files, shall be transferred to the County Court of the county. All statutory provisions relating to the county courts aforementioned of each county and to the Judge or Judges thereof shall apply to the new County Court of the county and the Judge or Judges thereof, unless otherwise provided by law. Until otherwise provided by law and except as aforestated, the judicial officers, surrogates and clerks of all courts now existing, other than those abolished in paragraph 3 hereof, and the employees of said officers, clerks, surrogates and courts shall continue in the exercise of their duties, as if this Constitution had not been adopted.

5. The Supreme Court shall make rules governing the administration and practice and procedure of the County Court; and the Chief Justice of the Supreme Court shall be the administrative head of these courts with power to assign any Judge thereof of any county to sit temporarily in the Superior Court or to sit temporarily without the county in a County Court.

6. The Advisory Masters appointed to hear matrimonial proceedings and in office on the adoption of this Constitution shall, each for the period of his term which remains unexpired at the time the Constitution is adopted, continue so to do as Advisory Masters to the Chancery Division of the Superior Court, unless otherwise provided by law.

7. All Special Masters in Chancery, Masters in Chancery, Supreme Court Commissioners and Supreme Court Examiners shall, until otherwise provided by rules of the Supreme Court, continue respectively as Special Masters, Masters, Commissioners and Examiners of the Superior Court, with appropriate similar functions and powers as if this Constitution had not been adopted.

8. When the Judicial Article of this Constitution takes effect: (a) All causes 
and proceedings of whatever character pending in the Court of Errors and Appeals shall be transferred to the new Supreme Court; (b) All causes and proceedings of whatever character pending on appeal or writ of error in the present Supreme Court and in the Prerogative Court and all pending causes involving the prerogative writs shall be transferred to the Appellate Division of the Superior Court; (c) All causes and proceedings of whatever character pending in the Supreme Court other than those stated shall be transferred to the Superior Court; (d) All causes and proceedings of whatever character pending in the Prerogative Court other than those stated shall be transferred to the Chancery Division of the Superior Court; (e) All causes and proceedings of whatever character pending in all other courts which are abolished shall be transferred to the Superior Court. For the purposes of this paragraph, paragraph 4 and paragraph 9 , a cause shall be deemed to be pending notwithstanding that an adjudication has been entered therein, provided the time limited for review has not expired or the adjudication reserves to any party the right to apply for further relief.

9. The files of all causes pending in the Court of Errors and Appeals shall be delivered to the Clerk of the new Supreme Court; and the files of all causes pending in the present Supreme Court, the Court of Chancery and the Prerogative Court shall be delivered to the Clerk of the Superior Court. All other files, books, papers, records and documents and all property of the Court of Errors and Appeals, the present Supreme Court, the Prerogative Court, the Chancellor and the Court of Chancery, or in their custody, shall be disposed of as shall be provided by law.

I0. Upon the taking effect of the Judicial Article of this Constitution, all the functions, powers and duties conferred by statute, rules or otherwise upon the Chancellor, the Ordinary, and the Justices and Judges of the courts abolished by this Constitution, to the extent that such functions, powers and duties are not inconsistent with this Constitution, shall be transferred to and may be exercised by Judges of the Superior Court until otherwise provided by law or rules of the new Supreme Court; excepting that such statutory powers not related to the Administration of justice as are then vested in any such judicial officers shall, after the Judicial Article of this Constitution takes effect and until otherwise provided by law, be transferred to and exercised by the Chief Justice of the new Supreme Court.

II. Upon the taking effect of the Judicial Article of this Constitution, the Clerk of the Supreme Court shall become the Clerk of the new Supreme 
Court and shall serve as such Clerk until the expiration of the term for which he was appointed as Clerk of the Supreme Court, and all employees of the Supreme Court as previously constituted, of the Clerk thereof and of the Chief Justice and the Justices thereof, of the Circuit Courts and the Judges thereof and of the Court of Errors and Appeals shall be transferred to appropriate similar positions with similar compensation and civil service status under the Clerk of the new Supreme Court or the new Supreme Court, or the Clerk of the Superior Court or the Superior Court, which shall be provided by law.

I2. Upon the taking effect of the Judicial Article of this Constitution, the Clerk in Chancery shall become the Clerk of the Superior Court and shall serve as such Clerk until the expiration of the term for which he was appointed as Clerk in Chancery, and all employees of the Clerk in Chancery, the Court of Chancery, the Chancellor and the several Vice Chancellors shall be transferred to appropriate similar positions with similar compensation and civil service status under the Clerk of the Superior Court or the Superior Court, which shall be provided by law.

I3. Appropriations made by law for judicial expenditures during the fiscal year one thousand nine hundred and forty-eight, one thousand nine hundred and forty-nine may be transferred to similar objects and purposes required by the Judicial Article.

I4. The Judicial Article of this Constitution shall take effect on the fifteenth day of September, one thousand nine hundred and forty-eight, except that the Governor, with the advice and consent of the Senate, shall have the power to fill vacancies arising prior thereto in the new Supreme Court and the Superior Court; and except further that any provision of this Constitution which may require any act to be done prior thereto or in preparation therefor shall take effect immediately upon the adoption of this Constitution.

\section{SECTION V}

I. For the purpose of electing senators in 1967 and until the 1970 decennial census of the United States for New Jersey shall have been received by the Governor, the forty senators are hereby allocated among fifteen Senate districts, as follows: First District - the counties of Gloucester, Atlantic and Cape May, two Senators; Second District - the counties of Salem and Cumberland, one senator; Third District - the county of Camden, three senators; Fourth District - the counties of Burlington and Ocean, two 
senators; Fifth District - the county of Monmouth, two senators; Sixth District - the county of Mercer, two senators; Seventh District - the county of Middlesex, three senators; Eighth District - the county of Somerset, one senator; Ninth District - the county of Union, three senators; Tenth District - the county of Morris, two senators; Eleventh District - the county of Essex, six senators; Twelfth District - the county of Hudson, four senators; Thirteenth District - the county of Bergen, five senators; Fourteenth District - the county of Passaic, three senators; and Fifteenth District - the counties of Sussex, Warren and Hunterdon, one senator.

2. For the purpose of electing members of the General Assembly and the senators from Assembly districts where so required in 1967 and until the 1970 census of the United States for New Jersey shall have been received by the Governor, the Assembly districts shall be established by an Apportionment Commission consisting of ten members, five to be appointed by the chairman of the State committee of each of the two political parties whose candidates for Governor receive the largest number of votes at the most recent gubernatorial election. Each State chairman, in making such appointments, shall give due consideration to the representation of the various geographical areas of the State. Such Apportionment Commission shall be appointed no earlier than November 10 nor later than November I5, 1966, and their appointments shall be certified by the Secretary of State on or before December I, 1966. The Commission, by a majority of the whole number of its members, shall certify the establishment of Assembly districts to the Secretary of State on or before February I, 1967.

3. If such Apportionment Commission fails so to certify the establishment of Assembly districts to the Secretary of State on or before the date fixed or if prior thereto it determines that it will be unable so to do, it shall so certify to the Chief Justice of the Supreme Court of New Jersey, and he shall appoint an eleventh member of the Commission. Such Commission, by a majority of the whole number of its members, shall within one month after the appointment of such eleventh member certify to the Secretary of State the establishment of Assembly districts.

4. The Assembly districts so established shall be used thereafter for the election of members of the General Assembly and shall remain unaltered until the following decennial census of the United States for New Jersey shall have been received by the Governor. Article XI, Section V, paragraphs I, 2, 3, 4 added effective December 8, 1966. 


\section{SECTION VI}

When this amendment to the Constitution providing for the abolition of the County Courts takes effect: (a) All the jurisdiction, functions, powers and duties of the County Court of each county, the judicial officers, clerks, employees thereof, and the causes pending therein, and their files, shall be transferred to the Superior Court. Until otherwise provided by law, the judicial officers, surrogates and clerks of the County Courts and the employees of said officers, clerks, surrogates and courts, shall continue in the exercise of their duties as if this amendment had not been adopted. For the purposes of this paragraph, a cause shall be deemed to be pending notwithstanding that an adjudication has been entered therein, provided the time limited for appeal has not expired or the adjudication reserves any party the right to apply for further relief. (b) All the functions, powers and duties conferred by the statute, rules or otherwise, upon the judges of the County Courts, shall be transferred to and may be exercised by judges of the Superior Court until otherwise provided by law or rules of the Supreme Court. (c) Until otherwise provided by law, all county clerks shall become clerks of the Law Division of the Superior Court and all surrogates shall become clerks of the Chancery Division (Probate Part) of the Superior Court for their respective counties and shall perform such duties and maintain such files and records on behalf of the Clerk of the Superior Court as may be required by law and rule of court; and all fees payable to the county clerks and surrogates prior to the effective date of this amendment shall continue to be so payable and be received for the use of their respective counties until otherwise provided by law. (d) The judges of the County Courts in office on the effective date of this amendment shall be judges of the Superior Court. All such judges who had acquired tenure on a County Court shall hold office as a judge of the Superior Court during good behavior, with all rights, and subject to all the provisions of the Constitution affecting a judge of the Superior Court, as though they were initially appointed to the Superior Court. All other judges of the County Courts shall hold office as judges of the Superior Court, each for the period of him term which remains unexpired on the effective date of this amendment; and if reappointed, he shall hold office during good behavior, with all the rights and subject to all the provisions of the Constitution affecting a judge of the Superior Court as though he were initially appointed to the Superior Court. Article XI, Section VI, added effective December 7, 1978. 